Revista de Derecho Público: Teoría y Método Marcial Pons Ediciones Jurídicas y Sociales

Vol. 2 | 2020 pp. 73-118 Madrid, 2020

DOI:10.37417/RPD/vol 22020523

(C) Dolores Utrilla Fernández-Bermejo ISSN: $2695-7191$

Recibido: 18/09/2020 | Aceptado: 30/09/2020

Editado bajo licencia Creative Commons Attribution 4.0 International License.

\title{
LA RELACIÓN JURÍDICA EN EL SISTEMA DE DERECHO ADMINISTRATIVO $^{1}$
}

\section{THE LEGAL RELATIONSHIP IN THE SYSTEM OF ADMINISTRATIVE LAW}

\author{
Dolores Utrilla Fernández-Bermejo \\ Profesora Contratada Doctora de Derecho Administrativo \\ Universidad de Castilla-La Mancha
}

RESUMEN: En el presente estudio se examina el rol desempeñado por la teoría de la relación jurídicoadministrativa tanto en el Derecho administrativo vigente como en su tratamiento dogmático, y se mantiene la tesis de que la ciencia del Derecho administrativo español debe incorporar a la parte general de la disciplina una teoría renovada de la relación jurídico-administrativa, como herramienta dirigida a posibilitar un adecuado análisis del ordenamiento administrativo desde la perspectiva de sus sujetos. Se justifica que la renovación de esta parte del sistema de Derecho administrativo, decantando sus problemas regulatorios típicos de las relaciones jurídico-administrativas y desarrollando una tipología de sus concreciones más características, puede constituir un instrumento valioso para diseñar, interpretar, aplicar y explicar el Derecho administrativo de manera

1 Trabajo finalizado el 18 de septiembre de 2020. Este artículo constituye una versión preliminar de un estudio en curso de elaboración. Sus líneas iniciales fueron presentadas por la autora en el Seminario de Teoría y Método (STEM) celebrado en la Universidad de Santiago de Compostela el 25 de mayo de 2018. Agradezco a los colegas que participaron en el Seminario sus valiosos comentarios y críticas, que han sido tenidos en cuenta en la presentación de la presente versión del trabajo.

Abreviaturas utilizadas: CE (Constitución Española de 1978); LGS (Ley 14/1986, de 25 de abril, General de Sanidad); LJCA (Ley 29/1998, de 13 de julio, reguladora de la Jurisdicción ContenciosoAdministrativa); LPACAP (Ley 39/2015, de 1 de octubre, del Procedimiento Administrativo Común de las Administraciones Públicas); LRJAP (Ley 30/1992, de 26 de noviembre, de Régimen Jurídico de las Administraciones Públicas y del Procedimiento Administrativo Común); LRJSP (Ley 40/2015, de 1 de octubre, de Régimen Jurídico del Sector Público); STC (Sentencia del Tribunal Constitucional); STJCE (Sentencia del Tribunal de Justicia de las Comunidades Europeas); STJUE (Sentencia del Tribunal de Justicia de la Unión Europea); TRLSRH (Texto Refundido de la Ley del Suelo y Rehabilitación Urbana, aprobado mediante Real Decreto Legislativo 7/2015, de 30 de octubre). 
más adecuada a sus presupuestos europeos, constitucionales y sectoriales. Por último, se identifican algunos de los elementos estructurales y metodológicos centrales que deberían integrarse en una futura agenda de investigación destinada a acometer esta tarea de reconstrucción sistemática en el plano del Derecho administrativo general.

PALABRAS CLAVE: relación jurídico-administrativa; Derecho administrativo general; posiciones jurídicas subjetivas; funciones administrativas; multipolaridad.

ABSTRACT: This paper explores the role performed by the theory of the legal relationship both in administrative law and in its theoretical treatment. It argues that Spanish administrative law scholars should incorporate a renewed theory on the legal relationship into the general part of the discipline, as a tool facilitating the analysis of administrative law from the perspective of its subjects. Identifying and developing a typology of the regulatory problems characteristic of legal relationships governed by administrative law can - so the argument goes-, be a useful source of criteria to design, interpret, enforce, and explain administrative law in full coherence with its European and constitutional foundations, as well as with its sector-based manifestations. Lastly, the paper isolates some of the central structural and methodological elements that should be included into a future research agenda aimed at renewing this part of the system of general administrative law.

KEYWORDS: legal relationship; general administrative law; subjective legal positions; administrative functions; multipolarity.

SUMARIO: 1. INTRODUCCIÓN.-2. ESTADO DE LA CUESTIÓN: 2.1. Presencia central en el Derecho administrativo. 2.2. Relegación en la ciencia del Derecho administrativo. 2.3. Reacciones.-3. RELEVANCIA CIENTÍFICA: 3.1. Argumentos en contra: 3.1.1. Impronta iusprivatista y liberal de la figura. 3.1.2. Inutilidad científica. 3.2. Argumentos a favor: 3.2.1. El rol central y las recientes transformaciones de la perspectiva subjetiva. 3.2.2. Las carencias de la perspectiva objetiva.-4. AGENDA DE INVESTIGACIÓN: ELEMENTOS ESTRUCTURALES Y METODOLÓGICOS: 4.1. Planteamiento. 4.2. Estructura: 4.2.1. En el nivel superior del sistema. 4.2.2. En el nivel intermedio del sistema. 4.3. Funciones: 4.3.1. Dogmática. 4.3.2. Práctica o de almacén. 4.3.3. Orientadora. 4.3.4. Integradora. 4.3.5. Heurística y comunicativa. 4.3.6. Complementaria y renovadora. 4.4. Materiales: 4.4.1. De alcance general. 4.4.2. De alcance sectorial: 4.4.2.1. La actividad prestacional del Estado social. 4.4.2.2. La autorregulación regulada. 4.4.2.3. La actividad de regulación y supervisión económica. 4.4.2.4. La adjudicación administrativa de recursos escasos. 4.4.2.5. Los daños legítimos.-5. BIBLIOGRAFÍA.

\section{INTRODUCCIÓN}

El ordenamiento jurídico regula relaciones entre sujetos de Derecho. En efecto, la mayoría de las normas de Derecho objetivo, cualquiera sea la rama del ordenamiento en que convencionalmente se encuadren, regulan en última instancia la posición jurídica de uno o varios sujetos en relación a otros. Se ha señalado por ello que el Derecho «no impone conductas a los individuos sino en razón de su dimensión social o 
relacional» ${ }^{2}$. El Derecho público no constituye una excepción a esta situación, como tampoco lo hace su parcela más acabada, el Derecho administrativo.

Desde hace largo tiempo, sin embargo, la construcción cientifica del Derecho administrativo en España-sobre todo por lo que respecta a su parte general- ha relegado a un segundo plano la perspectiva subjetiva (esto es, la dimensión relativa a las posiciones jurídicas correlativas de los sujetos que interactúan bajo normas de Derecho administrativo) para centrarse, de manera prioritaria, en su dimensión objetiva o formal. Dicho sea con todas las cautelas que exige cualquier generalización, la narrativa de la ciencia del Derecho administrativo español es una centrada en el lenguaje del Derecho objetivo, más que en el del derecho subjetivo y del resto de posiciones jurídicas de los sujetos disciplinados por esta rama del ordenamiento ${ }^{3}$.

Frente a este escenario de partida, en las páginas siguientes se mantiene la tesis de que la ciencia del Derecho administrativo español debe acometer la tarea de incorporar a la parte general de la disciplina una teoría renovada de la relación juridico-administrativa, como herramienta dirigida a posibilitar un adecuado análisis del ordenamiento administrativo desde la perspectiva de sus sujetos. Esta afirmación se sustenta, a su vez, en dos premisas. La primera de ellas es que complementar la construcción científica del Derecho administrativo a través de la perspectiva subjetiva es una exigencia derivada de la concepción constitucional y europea del ciudadano, así como de la propia Administración. La segunda es que esa complementariedad es irrenunciable como medio para superar las insuficiencias que una construcción doctrinal predominantemente objetiva o formal presenta para dar acabada respuesta a las necesidades de protección de los derechos individuales y de eficacia de la actuación administrativa en la satisfacción de los intereses generales.

Esta contribución pretende justificar la tesis recién expuesta, así como aportar algunos elementos estructurales y metodológicos útiles para la renovación de la teoría de la relación juridico-administrativa en el plano del Derecho administrativo general. Esta delimitación del objeto y la finalidad del estudio debe matizarse desde las cuatro perspectivas siguientes.

En primer lugar, y a efectos de claridad expositiva, conviene aclarar el sentido con que en este estudio se emplean las nociones de "perspectiva subjetiva», "teoría de la relación jurídico-administrativa», y «teoría de las posiciones jurídicas subjetivas». Los dos primeros conceptos se emplean como nociones paralelas, pero que operan en distintos planos. La aproximación subjetiva es una perspectiva de análisis, esto es, un ángulo de observación que contempla al ordenamiento desde la posición de los sujetos que interactúan bajo su disciplina. Por su parte, la teoría de la relación juridicoadministrativa se concibe en este trabajo como el instrumento teórico-metodológico necesario para acometer el análisis del Derecho administrativo en clave o perspectiva

2 Francisco VELASCO CABALlERO, Derecho público más Derecho privado, Marcial Pons, Madrid, 2014, pp. 23-24.

3 En sentido similar, Luis MEDINA ALCOZ, Libertad y autoridad en el Derecho administrativo. Derecho subjetivo e interés legítimo: una revisión, Marcial Pons, Madrid, 2016, pp. 95-96. 
subjetiva. Esta teoría incluye, entre otros extremos, la llamada doctrina de las situaciones jurídicas subjetivas, que es solamente una de sus partes (por cierto, la más desarrollada hasta ahora). En otras palabras: una relación jurídica es una conexión entre sujetos que detentan posiciones jurídicas subjetivas, pero no es solamente esto, sino que constituye también la estructura en las que esos sujetos interaccionan y modifican su posición a lo largo del transcurso de su interacción.

En este punto resulta necesario realizar dos precisiones adicionales, ambas referidas al alcance con que se maneja la noción de «subjetividad» o "perspectiva subjetiva». Por una parte, debe aclararse que este concepto se emplea aquí por oposición al análisis o perspectiva objetiva, que alude al interés por el estatuto jurídico de la Administración pública considerado en relación con el ordenamiento jurídico o Derecho objetivo $^{4}$. La perspectiva objetiva es, por tanto, un enfoque analítico en el que las nociones centrales son las de legalidad y $\operatorname{control}^{5}$, y en el que los sujetos que interactúan con la Administración no son contemplados prioritariamente como partes activas de dicha interacción, sino como meros objetos de la actuación administrativa.

De otro lado, es necesario tener en cuenta que la perspectiva subjetiva se concibe aquí como un ángulo de observación del Derecho administrativo políticamente neutro sin que, por lo tanto, quepa identificar esta forma de análisis con una defensa de postulados liberal-individualistas. La contemplación de las normas administrativas en clave subjetiva -articulada técnicamente a través de la teoría de la relación jurídica- es útil para incorporar al sistema de Derecho administrativo las posiciones jurídico-subjetivas de los distintos sujetos (tanto privados como públicos) sometidos a normas administrativas. Además, es una herramienta que permite optimizar la manera en que cada una de esas posiciones se despliega, con independencia de su respectivo contenido último (interés general o interés individual). En otras palabras: la aproximación en clave subjetiva al Derecho administrativo no solo puede servir para proteger mejor al ciudadano frente a los excesos del poder, sino también para mejorar el ejercicio por parte de la Administración de las funciones que le son propias.

En segundo lugar, y en estrecha conexión con lo anterior, se utiliza aqui la noción de relación jurídico-administrativa en sentido muy amplio. Se alude con ella a la idea ordenadora que encapsula el conjunto dinámico de posiciones jurídico-subjetivas recíprocas, tanto positivas como negativas, en que suelen encontrarse típicamente, dependiendo del contexto, los sujetos que interactúan entre sí bajo la disciplina de normas de Derecho administrativo. Como se indicará más adelante, precisamente uno de los pasos esenciales para la renovación de esta parte del Derecho administrativo general consiste en el replanteamiento del propio concepto de relación jurídico-

\footnotetext{
${ }^{4}$ Luciano PAREJO ALFONSO, Lecciones de Derecho administrativo, 8. ${ }^{\mathrm{a}}$ ed., Tirant lo Blanch, Valencia, 2016, p. 315.

5 Concretamente, se trata de un enfoque basado en una "comprensión formal y asocial del principio de legalidad», en expresión de Antonio ESTEBAN DRAKE, El derecho público subjetivo como instrumentación técnica de las libertades públicas y el problema de la legitimación procesal, Civitas, Madrid, 1981, p. 196.
} 
administrativa. En tanto que noción científica, esta habrá de formularse atendiendo primariamente a su finalidad ${ }^{6}$. De ello se deriva, por de pronto, que no se trata aquí de postular la formulación de una teoría lógico-formal de la relación jurídica equiparable a la existente en el Derecho privado, ni de defender una vuelta al individualismo propio de épocas pasadas, ni tampoco de negar la esencia política del Derecho público. Se trata, antes bien, de justificar la necesidad de (y ofrecer algunos elementos iniciales para) la reconstrucción sistemática de una teoría general de la relación jurídico-administrativa que se adapte a los parámetros normativos, institucionales y políticos vigentes del Derecho administrativo español y que, por lo tanto, sea útil para racionalizar y guiar la producción, interpretación, aplicación y explicación del Derecho positivo.

En tercer lugar, a pesar de la anunciada amplitud con que se manejará aquí la noción de relación jurídico-administrativa, quedan excluidas de consideración a los efectos de este estudio aquellas en las que no intervienen sujetos privados, sino únicamente Administraciones públicas y/o sus órganos (relaciones inter- e intraadministrativas). Se trata esta de una opción metodológica fundada en dos consideraciones. De una parte, este último tipo de relaciones encuentra ya un notable grado de desarrollo y actualización dogmática en el Derecho de la organización administrativa, entendido en sentido amplio. De otro lado, las relaciones jurídico-administrativas en que interviene al menos un sujeto privado plantean problemas regulatorios típicos y en buena medida diferentes a los que suscitan aquellas otras. Tales cuestiones, en fin, son lo suficientemente complejas y variadas como para que su tratamiento desde la parte general obligue a realizar un considerable esfuerzo de abstracción, con la consiguiente pérdida de precisión analítica, que se vería agudizada si el objeto de estudio se extendiese también a las relaciones inter- e intraadministrativas. Esta delimitación se realiza sin perjuicio de que el tratamiento científico de la relación jurídico-administrativa, en el sentido aquí propuesto, deba tener en cuenta (y ser susceptible de comunicación teórica con) la teoría de las relaciones inter- e intraadministrativas, en tanto que manifestaciones específicas de una figura común.

En cuarto lugar, se aspira aquí a presentar, de manera ordenada y contextualizada, solamente los argumentos que justifican la necesidad de renovación de la teoría de la relación jurídico-administrativa en la parte general del sistema de Derecho administrativo, así como a identificar algunos de los elementos centrales que habrán de tenerse en cuenta en dicha tarea. Significa esto que, lógicamente, con esta contribución (que forma parte de un trabajo más amplio en curso de elaboración) no se pretende ofrecer un marco completo y acabado para la reconstrucción de este segmento de la parte general de la disciplina. Un intento de similares características resultaría poco realista, como mínimo por los siguientes tres motivos. De una parte, por la inmensidad de la tarea, intensificada por el hecho de haber sido largamente preterida, con contadas

${ }^{6}$ Silvia DÍEZ SASTRE, La formación de conceptos en el derecho público. Un estudio de metodología académica: definición, funciones y criterios de formación de los conceptos jurídicos, Marcial Pons, Madrid, 2018, marg. 240, pp. 332 ss. 
excepciones, por parte de la doctrina española contemporánea. Esta circunstancia obliga a trabajar con un volumen de material normativo, jurisprudencial y doctrinal considerablemente mayor que en otras áreas de la parte general cuya teoría se ha decantado históricamente de forma más gradual e ininterrumpida. De otro lado, porque la relación jurídico-administrativa se encuentra presente, con relevantes diferencias y matices, en todos y cada uno de los distintos ámbitos sectoriales del Derecho administrativo, de manera que los sectores de referencia a tener en cuenta (y, por tanto, el volumen de fenómenos a sistematizar) crece también por esta vía. A todo ello se añade, en fin, que una construcción dogmática de este tipo es relativa en función del momento histórico y lugar en que se realice. Por lo tanto, no puede acometerse de una vez y para todas, sino que debe ser necesariamente revisada, corregida y actualizada de forma periódica.

El objeto y finalidad del estudio, así delimitados, encuentran reflejo en la estructura del trabajo. Este examina, en primer lugar, el rol desempeñado por la relación jurídico-administrativa en el Derecho administrativo vigente, así como en el tratamiento dogmático de la disciplina (infra 2). Sobre esta base, se justifica la relevancia científica de la figura (infra 3) y se proponen de manera sintética algunos de los elementos estructurales y metodológicos centrales que deberían integrarse en una futura agenda de investigación destinada a incorporar, en la parte general del Derecho administrativo, una teoría renovada de la relación jurídico-administrativa (infra 4).

\section{ESTADO DE LA CUESTIÓN}

\subsection{Presencia central en el Derecho administrativo}

La idea de relación jurídica, entendida como posición jurídica correlativa de los sujetos que interactúan bajo normas de Derecho administrativo, subyace a los elementos centrales de esta rama del ordenamiento positivo en la parte general y encuentra una presencia particularmente intensa y detallada en la parte especial. Esta presencia se manifiesta, en ocasiones, de manera expresa. Con mayor frecuencia, sin embargo, la misma se encuentra implícitamente en la base de construcciones positivas y teóricas de carácter objetivo o formal, esto es, pretendidamente alejadas de la idea de relación jurídica y centradas prioritariamente en la actuación del poder administrativo y en su control.

Sin ánimo de exhaustividad, pueden aportarse algunos ejemplos extraidos de la parte general que son representativos de lo que acaba de indicarse. Interesa ahora únicamente dejarlos apuntados; sobre algunos de ellos se volverá con mayor detalle después. En un primer plano de abstracción, la correlatividad de situaciones subjetivas a que remite la idea de relación jurídica ha sido tradicionalmente una noción relevante para definir el propio concepto de Derecho administrativo. Así se deriva de las variadas propuestas de delimitación de esta rama del ordenamiento como aquella que tiene por objeto la regulación del estatuto y de las relaciones jurídicas de las Admi- 
nistraciones públicas ${ }^{7}$. La noción también subyace a los conceptos de administrado o ciudadano (entendido como sujeto privado que establece relaciones jurídicas con una Administración pública) ${ }^{8}$ y a la delimitación positiva y dogmática de los conceptos de acto administrativo ${ }^{9}$ y reglamento ${ }^{10}$ (en este caso, sobre todo, por oposición a las meras circulares e instrucciones internas ${ }^{11}$ ): es rasgo común de todas estas nociones el utilizar como rasgo definitorio el tipo de efectos que cada una de ellas implica desde el punto de vista de las situaciones jurídicas de otros sujetos.

Asimismo, conviene recordar que las posiciones jurídicas correlativas de Administración y ciudadano han servido históricamente para definir y regular el régimen del acto administrativo y, sobre todo, del procedimiento administrativo ${ }^{12}$, institución que simboliza como pocas la posición del ciudadano ante la Administración y que se ha articulado tradicionalmente como mecanismo de defensa de aquel frente a esta ${ }^{13}$.

7 En España, entre otros: Manuel COLMEIRO, Derecho administrativo español. Tomo primero, 4. a ed., Imprenta y Librería de Eduardo Martínez, Madrid, 1876, p. 7; José GASCÓN Y MARÍN, Tratado de Derecho administrativo. Principios y legislación española. Tomo I, 5. a ed., C. Bermejo Impresor, Madrid, 1933, p. 60; Carlos GARCÍA OVIEDO, Derecho Administrativo I, 8. ${ }^{\text {a }}$ ed., EISA, Madrid, 1962 [edición a cargo de E. Martínez Useros], pp. 27-28; Manuel CLAVERO ARÉVALO, Estudios de Derecho administrativo, Instituto García Oviedo-Civitas, Madrid, 1992, p. 45; Eduardo GARCÍA DE ENTERRÍA y Tomás Ramón FERNÁNDEZ, Curso de Derecho Administrativo I, 17.a ed., Aranzadi, Cizur Menor, 2015, p. 445; Miguel SÁNCHEZ MORÓN, Derecho administrativo. Parte general, 13. a ed., Tecnos, Madrid, 2017, p. 445.

8 Joaquín TORNOS MAS, "Lección 1. Los ciudadanos y su posición jurídica", en Tomás CANO CAMPOS (coord.), Lecciones y materiales para el estudio del Derecho administrativo. Tomo IV. Las garantías de los ciudadanos y el control de las Administraciones públicas, Iustel, Madrid, 2009, pp. 13-30 (p. 17).

9 En Alemania, Otto MAYER, Deutsches Verwaltungsrechts. Band I, Duncker \& Humblot, Leipzig, 1895, p. 94: «declaración autoritaria que determina el derecho del súbdito en el caso concreto». En Francia, Maurice HAURIOU, Précis de droit administratif et de droit public, 11. a ed., Sirey, París, 1927, p. 256: «toda declaración de voluntad emitida por una autoridad administrativa en forma ejecutoria, es decir, en forma que implica la ejecución de oficio a fin de producir un efecto jurídico respecto a los administrados». En España, la presencia es muy clara, por ejemplo, en Recaredo FERNÁNDEZ DE VELASCO, El acto administrativo. Exposición doctrinal y estudio del Derecho español, Ed. Revista de Derecho Privado, Madrid, 1929, p. 15: «toda declaración jurídica, unilateral y ejecutiva, en virtud de la cual la Administración tiende a crear, reconocer, modificar o extinguir situaciones jurídicas subjetivas». En sentido similar, por ejemplo, Antonio ROYO-VILLANOVA, Elementos de Derecho Administrativo, 26. a ed., Librería Santarén, Valladolid, 1964, pp. 95 ss.; GARCÍA DE ENTERRÍA y FERNÁNDEZ, 2015: 589 .

10 GARCÍA DE ENTERRÍA y FERNÁNDEZ, 2015: 203 ss.

11 SÁNCHEZ MORÓN, 2017: 189-191. Como es sabido, la ausencia de efectos jurídicos sobre terceros es la regla general en el caso de las instrucciones o circulares internas, lo cual explica que (a diferencia de los reglamentos, sometidos al principio de publicidad propio de las normas jurídicas: art. 9.3 CE) solo sean de necesaria publicación oficial cuando «se estime conveniente por razón de los destinatarios o de los efectos que puedan producirse» (art. 6 LRJSP).

${ }_{12}$ Cfr. por ejemplo el preámbulo de la LPACAP, que utiliza los conceptos de relación jurídica ad intra y ad extra para clasificar el material normativo antes recogido en la LRJAP entre, respectivamente, las nuevas LRJSP y la LPACAP. Objeto de esta última es, según el propio preámbulo, «la regulación de las relaciones ad extra de las Administraciones con los ciudadanos».

13 Eberhard SCHMIDT-AßMANN, La teoría general del Derecho administrativo como sistema, Marcial Pons, Madrid, 2003, \$ 6/119); José María RODRÍGUEZ DE SANTIAGO, La administración 
En coherencia con ello, el concepto de interesado en el procedimiento depende de la titularidad de un derecho subjetivo o interés legítimo (art. 4 LPACAP); los vicios de forma y procedimiento adquieren relevancia invalidante, fundamentalmente, cuando producen indefensión (art. 48.2 LPACAP); existe obligación de motivar cuando se limitan derechos subjetivos o intereses legítimos, o cuando el acto es, por diversos motivos, desfavorable para el interesado (art. 35 LPACAP); el régimen de revisión de oficio y revocación de los actos encuentra límites diversos en función de la existencia o no de efectos favorables para los interesados (arts. 106 a 110 LPACAP); los medios de ejecución forzosa de los actos administrativos dependen del tipo de obligación impuesta por aquellos (arts. 97 a 104 LPACAP), etcétera.

Otro tanto sucede con el diseño del control jurisdiccional contencioso-administrativo, lugar donde la teoría de las posiciones jurídicas subjetivas alcanza su significado práctico más profundo. En este ámbito, cabe recordar que la protección de derechos subjetivos e intereses legítimos es el fundamento mismo de la jurisdicción (arts. 24.1 y 117.4 CE); que la titularidad de tales posiciones es la llave de acceso a la tutela judicial (arts. 24.1 CE y 19.1 LJCA) ${ }^{14}$; que la constelación de intereses en conflicto y su adecuada ponderación determina el régimen de las medidas cautelares (cfr. especialmente el art. 130 LJCA), así como de los términos en que hayan de producirse las relaciones entre tutela primaria (restitución) y tutela secundaria (resarcimiento) ${ }^{15}$; o, más en general, que de la teoría de las posiciones jurídicas subjetivas existente en cada ordenamiento dependen las funciones y efectos del control jurisdiccional, que pueden moverse en un espectro cuyos extremos ideales son la jurisdicción meramente objetiva, de un lado, y la jurisdicción plena, de otra parte ${ }^{16}$.

Un último ejemplo que merece la pena destacar ahora, y que se retomará después, es el de las clases o tipos de actividad de la Administración. La doctrina tradicional de los tipos administrativos, que tras someterse a sucesivos ajustes sigue vigente en buena medida entre nosotros, se formó en su momento en atención a las diferentes clases de relación jurídico-administrativa trabadas entre Administración y ciudadano según que la actuación realizada por el poder público consistiese bien en ordenar

del Estado Social, Marcial Pons, Madrid, 2007, p. 128; Javier BARNÉS VÁZQUEZ, "Introducción. Reforma e innovación del procedimiento administrativo", en Javier BARNÉS VÁZQUEZ (ed.), La transformación del procedimiento administrativo, Global Law Press, Sevilla, 2008, pp. 15-69, p. 15.

${ }_{14}$ Este diseño se encontraba ya presente en la Ley de la Jurisdicción de 22 de julio de 1894, cuyo art. 1 fijaba como requisito indispensable que las actuaciones administrativas impugnadas vulnerasen "un derecho de carácter administrativo establecido anteriormente en favor del demandante por una ley, un reglamento u otro precepto administrativo". Sobre esto, Jaime GUASP DELGADO, "El derecho de carácter administrativo como fundamento del recurso contencioso", Revista de la Facultad de Derecho de Madrid, núm. 2, 1940, pp. 11-23.

15 Silvia DÍEZ SASTRE, La tutela de los licitadores en la adjudicación de contratos públicos, Marcial Pons, Madrid, 2012; Silvia DÍEZ SASTRE, "La tutela de los competidores en los procedimientos administrativos de adjudicación", en Luis ARROYO JIMÉNEZ y Dolores UTRILLA FERNÁNDEZBERMEJO (dirs.), La administración de la escasez. Los fundamentos de la actividad administrativa de adjudicación de derechos limitados en número, Marcial Pons, Madrid, 2015, pp. 205-243.

16 En general, sobre esto, MEDINA ALCOZ, 2016. 
coactivamente actividades privadas, bien en fomentar esta, o bien en prestar un servicio público ${ }^{17}$. Se ha dicho por ello que la doctrina de los tipos administrativos se apoya sobre posiciones dogmáticas fundamentales que determinan la relación entre el particular y la Administración, a la luz de la función o tarea desarrollada en cada caso por esta y de las consiguientes necesidades de protección del individuo ${ }^{18}$.

Como se ha seńalado antes, la perspectiva subjetiva se encuentra presente de manera particularmente intensa en distintos ámbitos del Derecho administrativo sectorial y de su construcción teórica. Con frecuencia, las normas administrativas contienen enumeraciones y definiciones de las posiciones jurídicas activas y pasivas recíprocas que corresponden a la Administración y a los sujetos que se relacionan con ella en sectores materiales concretos, y/o se basan en tales posiciones subjetivas para diseñar las formas y medios de actividad administrativa. Son buenos ejemplos de ello el Derecho urbanístico ${ }^{19}$, la normativa sobre vivienda ${ }^{20}$, el Derecho medioambiental ${ }^{21}$, el Derecho de las prestaciones sanitarias ${ }^{22}$, o muy especialmente, el Derecho tributario, donde la regulación positiva y el tratamiento teórico de la relación jurídico-tributaria ha alcanzado un nivel de perfeccionamiento considerablemente elevado ${ }^{23}$.

La enumeración podría prolongarse mucho más, tanto en el plano general como sectorial, e incluso desbordando los márgenes de lo que tradicionalmente se ha entendido como Derecho administrativo en el paradigma del Estado-nación. Baste con mencionar ahora el que probablemente sea el ejemplo más paradigmático proveniente del Derecho de la Unión Europea: la vinculación del efecto directo de las normas europeas con la necesaria existencia de una obligación clara, precisa e incondicional, cuyo (in)cumplimiento afecte a la esfera de intereses de sujetos determinados ${ }^{24}$.

\subsection{Relegación en la ciencia del Derecho administrativo}

A pesar de cuanto acaba de indicarse, la narración y construcción cientifica contemporánea del Derecho administrativo tiende a relegar la dimensión subjetiva para adoptar

17 RODRÍGUEZ DE SANTIAGO, 2007.

18 SCHMIDT-ASSMANN, 2003: 148.

19 Probablemente el ejemplo más claro de ello sean los arts. 11 y ss. TRLSRH, que delimitan las facultades, deberes y cargas de los propietarios de cada tipo de suelo.

${ }^{20}$ Un ejemplo particularmente ilustrativo es el contenido en los arts. 12 y 13 de la Ley 2/2017, de 3 de febrero, de la Generalitat, por la función social de la vivienda en la Comunitat Valenciana.

${ }_{21}$ Me refiero fundamentalmente al derecho de acceso a la información ambiental, a la participación en la toma de decisiones, y al acceso a la justicia, cuyo reconocimiento en el Convenio de Aahrus (1998) ha transformado de manera formidable esta parte del Derecho administrativo europeo y nacional.

${ }_{22}$ Cfr. por ejemplo los arts. 10, 15, 67, 83, y 90.6 LGS.

23 Por todos, vid. José Luis PÉREZ DE AYALA, Dinámica de la relación jurídica tributaria en el Derecho español, Dykinson, Madrid, 1997.

${ }^{24}$ Así, desde la seminal STJUE de 5 de febrero de 1963, as. 26/62, Van Gend en Loos [1963]. Al respecto, por todos, Herwig C. H. HOFMANN y Catherine WARIN, "Identifying individual rights in EU law", University of Luxembourg Law Working Paper, núm. 4, 2017, 23 pp. 
una perspectiva objetiva o formal, esto es, centrada de manera muy acusada sobre la actuación administrativa, su eficacia y su control. Lo expresa claramente Esteve Pardo al indicar que «hasta tiempos recientes, la sociedad ha sido mero sujeto pasivo de la acción administrativa y por ello ha pasado inadvertida en los análisis y caracterizaciones del Derecho administrativo que lo concentraban exclusivamente en las Administraciones públicas» ${ }^{25}$.

Lo recién señalado es válido no solo para España, sino también para otros ordenamientos jurídicos de nuestro entorno -aunque, en ellos, la perspectiva subjetiva en el tratamiento teórico del Derecho administrativo nunca llegó a ser relegada con la misma intensidad, o bien lleva ya años siendo objeto de renovado interés científico-. Esta tendencia compartida a la objetivación del Derecho administrativo y de su tratamiento científico no es casual. Por el contrario, es consecuencia estructural del proceso de creación y evolución histórica del Derecho administrativo continental y, en concreto, del momento histórico en que este adquirió tintes profundamente autoritarios y antiliberales. Esta idea se desarrollará con mayor detalle en un epígrafe posterior de este trabajo (infra, 3.1.1). Baste por ahora con constatar que, en la actualidad, la objetivación de la ciencia del Derecho administrativo encuentra justificación renovada en la cláusula de Estado social ${ }^{26}$, y que se manifiesta incluso en los planteamientos doctrinales más vanguardistas e influyentes, como la llamada «nueva ciencia del Derecho administrativo» alemana (neues Verwaltungsrechtswissenschaft). En efecto, los autores enmarcados en esta comunidad científica consideran que su actividad debe enfocarse a la reconstrucción sistemática del Derecho objetivo, considerado como instrumento de actuación y dirección para el logro de metas públicas políticamente seleccionadas (Handlungs- und Steuerungsinstrument). En el seno de esta orientación, el individuo tiende a ser contemplado no en sus relaciones jurídicas con la Administración, sino como mero factor instrumental cuya relevancia depende de su conexión con la eficacia de la Administración en el cumplimiento de sus fines ${ }^{27}$.

Esta prolongada tendencia a la objetivación del Derecho administrativo y de su ciencia ha conducido a la casi total desaparición y en el absoluto desfase de la teoría de la relación juridico-administrativa en la construcción cientifica del Derecho administrativo general. En concreto, en España la relación jurídico-administrativa apenas ha sido aún objeto de desarrollo teórico. Y la única de sus partes que sí ha recibido atención - la doctrina de las situaciones jurídicas de ciudadano y Administración- no se ha renovado en la parte general de la disciplina, sino que, en el mejor de los casos, sigue tratándose en este plano a través de las construcciones heredadas, formalizadas durante el siglo XIX y, tras una intensa evolución, bien asentadas en nuestra doctrina

25 José ESTEVE PARDO, Lecciones de Derecho administrativo, 6. ${ }^{\mathrm{a}}$ ed., Marcial Pons, Madrid, 2016, p. 50.

26 MEDINA ALCOZ, 2016: 236.

27 Johannes MASING, "Der Rechtsstatus des Einzelnen im Verwaltungsrecht", en Wolfgang Hoffmann-Riem, Eberhard SCHMIDT-ASSMANN y Andreas VOSSKUHLE (eds.), Grundlagen des Verwaltungsrechts. Band I. Methoden. Masstässe. Aufgaben. Organisation, 2. ${ }^{\mathrm{a}}$ ed., C. H. Beck, Múnich, 2012, pp. 437-542 (pp. 440-446). 
y legislación positivas desde mediados del siglo xx. La ciencia española del Derecho administrativo sigue teniendo pendiente la labor de adecuar esta construcción a sus actuales presupuestos de Derecho constitucional y europeo, así como a los desarrollos presentes en el Derecho administrativo sectorial ${ }^{28}$.

Un repaso a la literatura jurídica de manual corrobora esta situación. Las obras contemporáneas españolas dedicadas al análisis y exposición del Derecho administrativo general relegan la contemplación de esta rama del ordenamiento en clave subjetiva y, por ello, propician un tratamiento meramente residual, testimonial y descriptivo a la teoría de la relación jurídico-administrativa. En muchas de estas obras, el tema ha desaparecido o, cuanto menos, ha dejado de ser objeto de atención monográfica ${ }^{29}$. A veces, bajo este rótulo (u otros similares) se aborda en realidad, ya sea principal o únicamente, el concepto positivo de ciudadano y/o de administrado, o bien la posición general de este ante la Administración, normalmente en los términos de la normativa general sobre procedimiento ${ }^{30}$. En el mejor de los casos, se limitan a reproducir de manera más o menos escueta las construcciones tradicionales acerca del concepto de derecho público subjetivo y de otras posiciones jurídico-subjetivas ${ }^{31}$. Además, allá donde las obras generales se detienen en este tema, lo hacen (prácticamente sin excepción) como introducción a la actividad de la Administración y su control, o bien al hilo del tratamiento de figuras nucleares de la disciplina que se explican desde una perspectiva objetiva (señaladamente, el contencioso-administrativo entendido como mecanismo de control de la Administración y de garantía del cumplimiento del Derecho objetivo). Esta situación contrasta vivamente, por cierto, con algunas de las principales sistematizaciones doctrinales realizadas por la doctrina española anterior, que reservaban un papel central a la teoría de la relación jurídica entre ciudadano y Administración ${ }^{32}$.

28 En sentido similar, MEDINA ALCOZ, 2016: 28.

29 Por ejemplo, no dedica atención separada al tema de la relación jurídico-administrativa, ni a las posiciones jurídico-subjetivas del ciudadano ante la Administración, en ninguno de los capítulos comprendidos en los catorce tomos de su Tratado Santiago MUNOOZ MACHADO, Tratado de Derecho Administrativo y Derecho Público General, 4. a ed., BOE, Madrid, 2015. Tampoco lo hacen otros autores como José BERMEJO VERA, Derecho administrativo básico. Parte General, 9.a ed., Thomso-Civitas, Cizur Menor, 2009; Germán FERNÁNDEZ FARRERES, Sistema de Derecho administrativo, Thomson-Civitas, Cizur Menor, 2012; Ramón MARTÍN MATEO y Juan José DÍEZ SÁNCHEZ, Manual de Derecho administrativo, 29. ${ }^{a}$ ed., Thomson Reuters, Cizur Menor, 2012; Luis MORELL OCANA, Curso de Derecho administrativo, 5. a ed., Servicio de Publicaciones Facultad de Derecho de la Universidad Complutense de Madrid, Madrid, 2002; Ramón PARADA VÁZQUEZ, Derecho administrativo (I, II, y III), 26. ${ }^{\mathrm{a}}$ ed., UNED Ediciones Académicas, Madrid, 2017; Juan Manuel TRAYTER JIMÉNEZ, Derecho administrativo. Parte general, 2. ${ }^{a}$ ed., Atelier, Barcelona, 2015.

${ }^{30}$ Así, Luis COSCULLUELA MONTANER, Manual de Derecho administrativo, 28. ${ }^{\mathrm{a}}$ ed., Thomson-Civitas, Cizur Menor, 2017; Eduardo GAMERO CASADO y Severiano FERNÁNDEZ RAMOS, Manual básico de Derecho administrativo, 14. a ed., Tecnos, Madrid, 2017; o Tornos Mas, 2009.

31 Manuel REBOLlO PUIG y Diego J. VERA JURADO (dirs.), Derecho Administrativo. Tomo I. Conceptos fundamentales. Fuentes y Organización, 3. ${ }^{a}$ ed., Tecnos, Madrid, 2017; Sánchez Morón, 2017.

${ }^{32}$ La relación jurídica de Derecho administrativo, o al menos la teoría de las situaciones jurídicas subjetivas, es objeto de atención específica en Manuel COLMEIRO, Derecho administrativo español. Tomo primero, Librerías de Don Ángel Calleja, Madrid-Santiago, 1850, p. 281, quien define la "ma- 
Ciertamente, la valoración precedente debe matizarse desde al menos dos puntos de vista. Por una parte, existen excepciones: algunas obras generales contemporáneas otorgan un lugar muy relevante a la relación jurídico-administrativa (así, el manual de Entrena Cuesta) ${ }^{33}$ o cuanto menos a la más clásica de sus partes: la teoría de las situaciones jurídicas subjetivas (en particular, los Fundamentos de Santamaría Pastor ${ }^{34}$, el Tratado de Garrido Falla ${ }^{35}$, y el Curso de García de Enterría y Fernández ${ }^{36}$ ). Aunque desde una perspectiva netamente distinta, la relación entre Estado y sociedad ocupa también una posición central en las Lecciones de Esteve Pardo ${ }^{37}$. De otro lado, debe tenerse en cuenta la finalidad fundamentalmente didáctica y descriptiva de las obras generales que han sido citadas, que impone sobre ellas severas limitaciones en

teria administrativa" como los deberes y los derechos de la Administración en cuanto a las personas, y en esa clave examina los diferentes ámbitos de actividad administrativa. También se aborda la cuestión con cierto detalle en Sabino ÁLVAREZ-GENDÍN, Tratado General de Derecho Administrativo. Tomo I, Bosch, Barcelona, 1958; José Luís VILLAR PALASÍ, Apuntes de Derecho Administrativo I. Servicio de Publicaciones del SEU del DU, Madrid, 1955; José Antonio GARCÍA-TREVIJANO FOS, Curso de Derecho Administrativo. Tomo I, Vol. 1, Sección de Publicaciones del SEU de Salamanca, Salamanca, 1961; García Oviedo, 1962, quien dedica buena parte del primer tomo de su Derecho administrativo, casi íntegramente, a la "doctrina de las relaciones entre Administración y administrados", tema que divide entre la consideración subjetiva -donde incluye la teoría de las posiciones jurídico-subjetivas de ciudadano y Administración (pp. 175-187) - y la consideración objetiva (donde incluye las formas y clases de actividad administrativa); y Royo-Villanova, 1964. Por el contrario, el rol de la figura es residual, o bien inexistente, en Adolfo POSADA HERRERA, Tratado de Derecho administrativo según las teorías filosóficas y la legislación positiva, Librería General de Victoriano Suárez, Madrid, 1898; Fernando MELLADO, Tratado elemental de Derecho administrativo, 2. a ed., Tipografía de los hijos de M. G. Hernández, Madrid, 1894; Vicente SANTAMARÍA DE PAREDES, Curso de Derecho administrativo según sus principios generales y la legislación actual de España, 8. a ed., Imprenta Española, Madrid, 1914; y Gascón y Marín, 1933.

33 Rafael ENTRENA CUESTA, Curso de Derecho administrativo. Volumen I/1: Concepto, fuentes, relación jurídico-administrativa y justicia administrativa, 12. ${ }^{a}$ ed., Tecnos, Madrid, 1998, pp. 153 ss. También destaca la importancia de la relación jurídica en el sistema de Derecho administrativo actual Luciano PAREJO ALFONSO, La vigilancia y la supervisión administrativas: un ensayo de su construcción como relación jurídica, Tirant lo Blanch, Valencia, 2016, pp. 315-318.

34 En efecto, Juan Alfonso SANTAMARÍA PASTOR, Fundamentos de Derecho administrativo I, Centro de Estudios Ramón Areces, Madrid, 1988, dedica un capítulo entero a las estructuras subjetivas (pp. 825-957), y se ocupa en concreto de las situaciones jurídicas subjetivas (pp. 874-904), aunque incluye también aquí elementos de teoría general de la organización administrativa (pp. 905 ss.). La sistematización se mantiene, aunque reducida en extensión, en Juan Alfonso SANTAMARÍA PASTOR, Principios de Derecho Administrativo General I, 3. a ed., Iustel, Madrid, 2015.

35 Con notoria influencia de la doctrina extranjera, principalmente italiana, Fernando GARRIDO FALLA, Tratado de Derecho Administrativo. Volumen I (Parte General), 2. a ed., Instituto de Estudios Políticos, Madrid, 1961, pp. 281-349; Fernando GARRIDO FALLA (con Alberto PALOMAR OLMEDA y Herminio LOSADA GONZÁLEZ), Tratado de Derecho Administrativo. Vol. I. Parte General, 14. ${ }^{\text {a }}$ ed., Tecnos, Madrid, 2003, pp. 514-542.

36 Eduardo GARCÍA DE ENTERRÍA y Tomás Ramón FERNÁNDEZ, Curso de Derecho Administrativo II, 14. a ed., Aranzadi, Cizur Menor, 2015, pp. 17-102.

37 ESTEVE PARDO, 2016, toma como eje ordenador del Derecho administrativo general las nuevas relaciones entre Estado y sociedad (rectius: el nuevo reparto de funciones entre ambos), pero para fijarse no en sus relaciones jurídicas, sino en la realización de actividades públicas por sujetos privados y en la correlativa expansión del ámbito de aplicación del Derecho administrativo. 
cuanto a su extensión y profundidad en el tratamiento de los temas. En cualquier caso, sí parece posible extraer la conclusión de que, en términos generales, la ciencia española contemporánea del Derecho administrativo parece no otorgar a la relación juridico-administrativa un rol relevante a la hora de acometer las sistematizaciones y exposiciones generales de la disciplina. Así lo confirma el hecho de que tampoco existan, por el momento, monografías dedicadas al estudio de esta figura en cuanto tal.

\subsection{Reacciones}

Existen ya algunas reacciones frente a la situación que acaba de ser descrita. En Espa$\tilde{n} a$, varios autores han señalado durante los últimos años la necesidad de acudir a la perspectiva subjetiva para abordar el tratamiento dogmático de determinados modos de actuación administrativa que desbordan los márgenes de la dogmática objetiva tradicional ${ }^{38}$. En esta línea, algunos han comenzado ya la tarea de revisar la entera teoría de la relación jurídica de Derecho administrativo ${ }^{39}$, la doctrina de las situaciones jurídico-subjetivas del ciudadano ${ }^{40}$, o han destacado la utilidad ordenadora de la construcción de una tipología de relaciones jurídico-administrativas ${ }^{41}$.

Un proceso de revitalización similar, aunque considerablemente más intenso, ha tenido comienzo varias décadas atrás en el que probablemente sea el país que mayor influencia académica despliega sobre el Derecho administrativo español contemporáneo: Alemania. Debido -fundamentalmente- a la configuración tuitiva de derechos de su contencioso-administrativo, la aproximación subjetiva al Derecho administrativo nunca llegó allí a quedar relegada de la misma manera que entre $\operatorname{nosotros}^{42}$. Sin embargo, el tratamiento teórico de la relación jurídico-administra-

38 Así, recientemente, Dolors CANALS I AMETLLER, "Principios, reglas y garantías propias del Derecho público en la prestación privada de servicios económicos de interés general", Revista Española de Derecho Administrativo, núm. 158, 2013, pp. 127-155; Dolores UTRILLA FERNÁNDEZBERMEJO, Expropiación forzosa y beneficiario privado. Una reconstrucción sistemática, Marcial Pons, Madrid, 2015; PAREJO ALFONSO, 2016; José María BAÑO LEÓN, "Derecho al procedimiento en la relación administrativa multipolar (los derechos fundamentales como límite a la renuncia del legislador al control previo de actuaciones)", Revista Española de Derecho Administrativo, núm. 189, 2018, pp. 47-64.

39 Jorge GARCÍA-ANDRADE GÓMEZ, Actuaciones administrativas sin procedimiento (relaciones jurídicas en el Estado de Derecho), en prensa.

40 MEDINA ALCOZ, 2016.

41 Por ejemplo, desde la perspectiva del reparto competencial sobre la legislación de procedimiento administrativo, Marcos VAQUER CABALLERÍA, "La codificación del procedimiento administrativo en España”, Revista General de Derecho Administrativo, núm. 42, 2016.

${ }_{42}$ Albert BLECKMANN, Zur Dogmatik des Allgemeinen Verwaltungsrechts I. Die Handlungsmittel der Verwaltung in rechtsvergleichender Sicht, Nomos, Baden-Baden, 1999, p. 127. Por ejemplo, la relación jurídico-administrativa y la teoría del derecho público subjetivo ocupan un lugar nuclear en las clásicas exposiciones de Walter JELLINEK, Verwaltungsrecht, 2. a ed., Springer, Berlín, 1929, pp. 179205; Fritz FLEINER, Instituciones de Derecho Administrativo, Editorial Labor, Barcelona, 1933 [trad. de la 8. a edición alemana por S. Álvarez Gendín), pp. 107-182, especialmente pp. 122-145); Adolf MERKL, Teoría general del Derecho administrativo, Editorial Revista de Derecho Privado, Madrid, 1935 
tiva constituye un fenómeno relativamente reciente, cuyos inicios suelen datarse en $1965^{43}$. A partir, fundamentalmente, de las reuniones de la Vereinigung der Deutschen Staatsrechtslehrer de 1971 en Ratisbona y de 1986 en Múnich, la figura de la relación jurídico-administrativa y su potencial dogmático comenzaron a ser objeto de intensa discusión doctrinal ${ }^{44}$. Como consecuencia de ello, desde la década de 1990 es habitual la presencia de estudios específicos sobre la relación jurídico-administrativa en los manuales y tratados contemporáneos de Derecho administrativo general alemán ${ }^{45}$. Este renovado interés se ha plasmado, además, en el desarrollo de un buen número de explicaciones sistemáticas de figuras generales y sectoriales del Derecho administrativo alemán enfocadas desde una perspectiva subjetiva ${ }^{46}$.

[edición al cuidado de J. L. Moreneo Pérez], pp. 171-184; y Ernst FORSTHOFF, Tratado de Derecho administrativo, Instituto de Estudios Políticos, Madrid, 1958 [5. a ed. alemana, trad. Legaz Lacambra, Garrido Falla y Gómez de Ortega y Junge], pp. 252-276.

${ }_{43}$ Matthias JESTAEDT, "Rechts als Relation. Skizzenhafte Anmerkungen zur Rechtsverhältnislehre", en Katharina GRÄFIN VON SCHLIEFFEN (ed.), Republik - Rechtsverbältnis - Rechtskultur, Mohr Siebeck, Tübingen, 2018, pp. 211-224 (p. 212).

44 Véase sobre todo Hans H. RUPP, Grundfragen der heutigen Verwaltungsrechtslehre. Verwaltungsrechtsnorm und Verwaltungsrechtsverbältnis, Mohr, Tübingen, 1965; Wilhelm HENKE, Das subjektive öffentliche Recht, Mohr, Tübingen, 1968; Wilhelm HENKE, W., "Die Rechtsformen der sozialen Sicherung und das Allgemeine Verwaltungsrecht", Veröffentlichungen der Vereinigung der Deutschen Staatsrechtslehrer, núm. 28, 1970, pp. 149-185; Peter HÄBERLE, Die Verfassung des Pluralismus, Athenaeum, Königstein, 1980; y Rolf GRÖSCHNER, "Vom Nutzen des Verwaltungsrechtsverhältnisses", Die Verwaltung, núm. 30, 1997, pp. 301-338.

45 Rolf GRÖSCHNER, Das Überwachungsrechtsverhältnis: Wirtschaftsüberwachung in gewerbepolizeirechtlicher Tradition und wirtschaftsverwaltungsrechtlichem Wandel, Mohr, Tübingen, 1992, p. 149, con ulteriores referencias). Baste a estos efectos la cita de Norbert ACHTERBERG, Allgemeines Verwaltungsrecht. Ein Lehrbuch, 2. ed., C. F. Müller, Heidelberg, 1986, pp. 331-364 y 519-547; Hartmut MAURER, Derecho administrativo. Parte General, Madrid, Marcial Pons, 2011, cap. 8, marg. 17-33; y MASING, 2012.

46 Así, por lo que respecta a la teoría de los vicios procedimentales, Hermann HILL, Das fehlerhafte Verfahren und seine Folgen im Verwaltungsrecht, Decker, Heidelberg, 1986, pp. 258 ss. En el ámbito de la tutela cautelar, Friedrich SCHOCH, Vorläufiger Rechtsschutz und Risikoverteilung im Verwaltungsrecht, Decker, Heidelberg, 1988, pp. 161 ss., 509 ss. Sobre las relaciones jurídicas multipolares, Rainer WAHL y Johannes MASING, "Schutz durch Eingriff", Juristen Zeitung, núm. 12, 1990, pp. 553563; Peter M. HUBER, Konkurrenzschutz im Verwaltungsrecht. Schutzanspruch und Rechtsschutz bei Lenkungs- und Verteilungsentscheidungen der öffentlichen Verwaltung, Mohr, Tübingen, 1991; y Matthias SCHMIDT-PREUSS, Kollidierende Privatinteressen im Verwaltungsrecht. Das subjektive öffentliche Recht im multipolaren Verwaltungsrechtsverhältnis, Duncker \& Humblot, Berlín, 1992. Acerca de la actividad administrativa de supervisión de la economía, GRÖSCHNER, 1992. En el contexto de la actuación administrativa informal, Martin SCHULTE, Schlichtes Verwaltungshandeln. Verfassungs- und verwaltungsrechtsdogmatische Strukturüberlegungen am Beispiel des Umweltrechts, Mohr, Tübingen, 1995. En general, sobre el significado de la relación jurídica desde la teoría del Derecho, Norbert ACHTERBERG, Die Rechtsordnung als Rechtsverhältnisordnung: Grundlegung der Rechtsverhältnistheorie, Duncker \& Humblot, Berlín, 1982. Desde el Derecho administrativo, Otto BACHOF, "Die Dogmatik des Verwaltungsrechts vor den Gegenwartsaufgaben der Verwaltung”, VVDStRL, núm. 30, 1972, pp. 193-244; Hartmut BAUER, "¿Transformación radical en la doctrina del Derecho administrativo? Las formas y las relaciones jurídicas como elementos de una dogmática jurídico-administrativa actual”, Documentación Administrativa, núm. 234, 1993, pp. 133-160; y los trabajos recogidos en el número monográfico de Die Verwaltung, vol. 30, núm. 3/1997. 
En Italia, el fortalecimiento del interés científico por las relaciones jurídico-administrativas (rapporti giuridici di diritto amministrativo) se produjo de manera más temprana, durante la primera mitad del siglo $\mathrm{xx}^{47}$. Desde entonces, la figura de la relación jurídica ha sido utilizada allí como elemento ordenador de algunas de las más destacadas exposiciones teóricas del Derecho administrativo general (como las de Vitta ${ }^{48}$, Forti ${ }^{49}$, Sandulli ${ }^{50}$, Alessi ${ }^{51}$, Zanobini ${ }^{52}$, Giannini ${ }^{53}$, y Cassese ${ }^{54}$ ), además de encontrar un desarrollo destacado en las obras de Carnelutti ${ }^{55}$, Cassarino ${ }^{56} \mathrm{y}$ Romano ${ }^{57}$. No obstante, se ha criticado en Italia que, tradicionalmente, la atención dedicada al individuo en la ciencia del Derecho administrativo ha sido muy limitada (como mero sujeto pasivo de la potestad administrativa hasta mediados del siglo xx), así como que «la construcción del interés legítimo, debido a su amplitud y complejidad, ha oscurecido la importancia de las posiciones y de las situaciones jurídicas propias del particular en sus relaciones con la Administración pública» ${ }^{58}$.

Francia ha sido el país de nuestro entorno donde la aproximación en clave subjetiva y, con ello, la teoría de la relación jurídica, han tardado más tiempo en introducirse en el Derecho administrativo y en su construcción científica. Tradicionalmente, las exposiciones generales de la disciplina han hecho alusión allí a estos extremos de manera extremadamente residual, y solo a los efectos de construir el sis-

47 A ello hacen referencia expresa Cino VITTA, Diritto amministrativo. Volume primo. Parte generale, Unione tipografico - Editrice torinese, Turín, 1933, pp. 93-94, y Ugo FORTI, Diritto amministrativo. Parte generale. Volume II. Il rapporto - La teoria degli atti, 4. ${ }^{\mathrm{a}}$ ed., Casa editrice Dott. Eugenio Jovene, Nápoles, 1947, p. 2.

48 VITTA, 1933: 92-112 comienza su obra con las nociones preliminares de Derecho objetivo y derecho público subjetivo, y dedica atención monográfica a las relaciones de Derecho público.

49 FORTI, 1947, utiliza la figura para explicar la teoría del acto administrativo.

50 Aldo M. SANDULLI, Manuale di diritto amministrativo, Casa editrice dott. Eugenio Jovene, Napoli, 1952, comienza examinando las situaciones subjetivas de derecho administrativo (pp. 40-76).

51 Renato ALESSI, Sistema istituzionale del Diritto amministrativo italiano, 2. ${ }^{a}$ ed., Giuffrè, Milán, 1958, estructura su Sistema en torno a tres partes: el sujeto activo de la función administrativa, el sujeto pasivo de la misma (donde estudia, entre otras materias, la teoría de las situaciones jurídicas subjetivas) y el control de legalidad.

52 Guido ZANOBINI, Corso di Diritto amministrativo. Volume primo. Principî generali, 8. ${ }^{\mathrm{a}}$ ed., Giuffrè, Milán, 1958, dedica cuatro lecciones al tema de las relaciones jurídicas de Derecho administrativo.

53 Massimo Severo GIANNINI, Diritto amministrativo. Volume secondo, 3. a ed., Giuffrè, Milán, 1993, dedica un capítulo íntegramente al tema de las situaciones jurídicas subjetivas (pp. 45-90).

54 Sabino CASSESE, Las bases del Derecho administrativo, INAP, Madrid, 1994 [original italiano de 1989, trad. de Luis Ortega], pp. 365-373, se ocupa del rol del ciudadano en el Derecho administrativo.

55 Francesco CARNELUTTI, Teoría general del Derecho, Comares, Granada, 2003 [trad. del original de 1940 por Carlos G. Posada], pp. 151-215.

56 Sebastiano CASSARINO, Le situazioni giuridiche e l'oggetto della giurisdizione amministrativa, Giuffrè, Milano, 1956.

57 Santi ROMANO, Frammenti di un Dizionario giuridico, Giuffrè, Milano, 1983, pp. 91-110 y $172-203$.

58 CASSESSE, 1994: 365 y 369. 
tema de la jurisdicción administrativa como mecanismo de garantía del principio de legalidad ${ }^{59}$.

También en el ámbito del Derecho de la Unión Europea parece existir un incipiente interés académico por la aproximación subjetiva y, en concreto, por la construcción de una teoría sobre los derechos individuales de los ciudadanos y empresas en sus relaciones con la Administración europea y nacional ${ }^{60}$. Ello no resulta extraño si se tiene en cuenta que la progresiva tendencia hacia la aproximación subjetiva al Derecho administrativo en los Estados miembros responde, en buena medida, a la influencia del Derecho de la Unión ${ }^{61}$, especialmente debido a la presión ejercida por las normas europeas relativas al reconocimiento de derechos fundamentales y por la decantación de las nociones de efecto directo y efectividad del Derecho de la Unión. Sobre ello se volverá después (infra, 3.2.1).

\section{RELEVANCIA CIENTÍFICA}

\subsection{Argumentos en contra}

Las razones tradicionalmente aducidas contra el análisis del Derecho administrativo en clave subjetiva pueden reconducirse a dos argumentos principales, en buena medida relacionados entre sí: la impronta iusprivatista y liberal de la noción de relación jurídica (infra 3.1.1) y su escaso potencial científico (infra 3.1.2). La exposición que sigue pretende sintetizar el contenido principal de estos argumentos, así como enjuiciar su consistencia a la luz de los parámetros actuales de producción, aplicación y tratamiento teórico del Derecho administrativo. Se adelanta aquí una crítica oponible a ambos: su potente trasfondo ideológico, más que racional o cientifico. Es el sesgo autoritario de la dogmática tradicional (basada en las nociones de Administración, legalidad, interés general, Derecho objetivo y control) lo que se oculta tras el rechazo a la aproximación subjetiva al Derecho administrativo. Más que dificultades técnicas,

59 Así, por ejemplo, en Vittorio Emmanuele ORLANDO, Principios de Derecho Administrativo, INAP, Madrid, 1978 [trad. de la 2a ed. Italiana, de 1892, por A. Rodríguez Bereijo), pp. 229-232 y 268-272, y en V. E. ORLANDO (1978: 229-232 y 268-278) y René CHAPUS, Droit administratif général, 14a ed., Montchrestien, París, 2000.

${ }^{60}$ Angela WARD, Judicial Review and the Rights of Private Parties in EC Law, Oxford University Press, Oxford, 2000; Albertina ALBORS-LLORENS, Private Parties in EC Law, Oxford University Press, Oxford, 2006; Loïc AZOULAI, Ségolène Barbou des Places y Etienne Pataut (eds.), Constructing the Person in EU Law: Rights, Roles, Identities, Hart Publishing, Oxford, 2016; Joana MENDES, Participation in EU Rulemaking. A Rights-Based Approach, Oxford University Press, Oxford, 2011; Bjarte THORSON, Individual Rights in EU Law, Springer, Suiza, 2016; HOFMANN y WARIN, 2017; Catherine WARIN, Individual Rights Under European Union Law: A Study on the Relation Between Rights, Obligations and Interests in the Case Law of the Court of Justice, Nomos, Baden-Baden, 2019; Julie RONDU, L'individu, sujet du droit de l'Union européenne, Bruylant, París, 2020.

61 Jean-Bernard AUBY, "The Transformation of the Administrative State and Administrative Law", en Armin VON BOGDANDY, Peter M. HUBER y Sabino CASSESE (eds.), The Administrative State. Volume 1, Oxford University Press, Oxford, 2017, pp. 601-630 (pp. 625-626). 
es la costumbre cultural la que hace extrańa una ciencia del Derecho administrativo explicada con el vocabulario de la relación jurídica ${ }^{62}$.

\subsubsection{Impronta iusprivatista y liberal}

El primero, y más extendido, de los argumentos aducidos contra la aplicación de la noción de relación jurídica al ámbito del Derecho administrativo, es su consideración como elemento ajeno a este y a su lógica, como figura importada del campo del Derecho privado y, por lo tanto, ligada al paradigma liberal de la correlatividad entre Derecho objetivo y derecho subjetivo. Este argumento se basa, en última instancia, en la afirmación decimonónica de la summa divissio, entendida como separación rígida entre Derecho privado (justicia conmutativa) y Derecho público (justicia distributiva), de conformidad con la cual únicamente en el segundo de estos ámbitos se encontraría autorizado el poder público a perseguir fines dirigidos a la protección del colectivo.

Esta concepción de la summa divisio permitió reducir la protección jurídica del individuo frente al poder y, con ello, posibilitó la emancipación del Derecho administrativo como rama del ordenamiento jurídico. Mientras que en el ámbito privado todo el Derecho objetivo se traducía en correlativos derechos subjetivos, en el Derecho público esa correlatividad desaparecía, y el foco de atención se trasladaba únicamente al Derecho objetivo y al control de su cumplimiento. Por ello, en el Derecho administrativo, la figura de la relación jurídica quedó relegada a una posición accesoria. Desde este prisma, las posiciones jurídicas del administrado que interactúa con la Administración importan únicamente en tanto que mecanismos de activación del proceso contencioso, considerado como mecanismo de control de legalidad de la actuación administrativa. Como es sabido, este es el problema más acuciante que subyace a la configuración clásica del contencioso objetivo francés ${ }^{63}$.

Cabe mantener que el potencial justificador de este argumento se ha erosionado en la misma medida en que lo han hecho los criterios tradicionales de distinción entre Derecho público y Derecho privado ${ }^{64}$. Debe recordarse que, por una parte, la unidad axiológica de todo el ordenamiento jurídico operada a través de la Constitución ha restado capacidad explicativa a las teorías que fundan en criterios sustantivos la summa divisio en criterios sustantivos. En particular, tanto la protección del interés general como el rol de la autonomía de la voluntad y la igualdad de los sujetos en la relación han dejado de ser características irrenunciables y exclusivas del Derecho público y del Derecho privado, respectivamente. De otro lado, la creciente tendencia a la pérdida de referencias subjetivas de las normas - potenciada, principalmente por el Derecho

62 MEDINA ALCOZ, 2016: 190-191.

63 Una síntesis de su configuración inicial y de su evolución hasta un sistema de justicia subjetiva en Eduardo GARCÍA DE ENTERRÍA, Problemas del Derecho público al comienzo de siglo, Civitas, Madrid, 2001.

64 Sobre esta erosión, por todos, VELASCO CABALLERO, 2014: 30 ss., 81 ss. 
de la Unión Europea-, ha restado fuerza ordenadora a los criterios de distinción subjetivos entre Derecho público y privado. No se niega con ello, obviamente, que el Derecho público (administrativo) siga presentando perfiles propios que exigen, asimismo, herramientas específicas para su tratamiento científico. Lo que pretende ponerse de relieve es, simplemente, que estas diferencias han dejado de ser nítidas y que no justifican per se el rechazo hacia el uso complementario de figuras convencionalmente adscritas en exclusiva al ámbito del Derecho privado.

El rechazo doctrinal contemporáneo fundado en el argumento que acaba de ser descrito puede conectarse, a su vez, con la necesidad histórica de autoafirmación de la ciencia del Derecho administrativo frente a la propia del Derecho civil. En la atención prioritaria al status de la Administración frente a la legalidad objetiva -y en la consiguiente elaboración de una narrativa teórica alejada de la idea de relación jurídica intersubjetiva- radicó, precisamente, la construcción del Derecho administrativo como disciplina científica autónoma ${ }^{65}$. En el intento por superar el antiguo sentimiento de inferioridad frente a la ciencia multisecular del Derecho civil, la búsqueda de dignidad teórica y de identidad para la ciencia del Derecho administrativo se encauzó a través de la exacerbación de sus diferencias con la propia del Derecho privado, y en la consiguiente percepción de la primera como una realidad separada, autosuficiente e impermeable a cualquier influencia proveniente de la segunda ${ }^{66}$. Es en este contexto donde cobra sentido la afirmación de que el Derecho administrativo «repudia en bloque al Derecho privado» ${ }^{67}$. Ello condujo, por lo que ahora interesa, a la adscripción exclusiva $-\mathrm{y}$ no siempre justificada - de ciertas categorías, como la de relación jurídica, al ordenamiento civil ${ }^{68}$.

El peculiar contexto académico en que se forjó esta visión permite, cuando menos, poner en entredicho su validez como argumento para rechazar actualmente el uso de la figura aquí examinada en la construcción científica del Derecho administrativo. El hecho de que la teoría de la relación jurídica encontrase desarrollo y perfeccionamiento inicialmente en el Derecho civil obedece a razones históricas y circunstanciales, y no permite concluir sin más que deba considerarse un monopolio de esta rama del Derech ${ }^{69}$. Por el contrario, se trata de una categoría jurídica transversal o general cuya configuración no necesariamente ha de atenerse a las características iusprivatistas y liberales que su surgimiento histórico le confirió ${ }^{70}$. Como se ha dicho ya, en tanto

${ }^{65}$ Ello es claramente visible, por ejemplo, en Maurice HAURIOU, "Préface", en su obra Précis de droit administratif et de droit public, 8. ${ }^{\text {a }}$ ed., Sirey, París, 1914, pp. V-VIII, quien en su día reivindicaba la naturaleza particular y autónoma del Derecho administrativo, debido a que esta rama del Derecho «en lugar de fundarse, como el civil, en la igualdad de las partes, lo hace sobre el estatuto especial y las prerrogativas de las partes más poderosas».

66 SANTAMARÍA PASTOR, 1988: 55-56.

67 Georges VEDEL, Droit Administratif I, Presses Universitaires de France, París, 1958, citado por Sebastián MARTÍN-RETORTILLO BAQUER, El Derecho civil en la génesis del Derecho administrativo $y$ de sus instituciones, 2. ${ }^{\text {a }}$ ed., Civitas, Madrid, 1996, p. 30.

68 MARTÍN-RETORTILLO BAQUER, 1996: 47 ss.

69 MARTÍN-RETORTILLO BAQUER, 1996: 22.

70 Santi ROMANO, L'ordinamento giuridico, Sansoni, Firenze, 1951, p. 8. 
que herramienta para acometer el análisis del Derecho administrativo en perspectiva subjetiva, la teoría de la relación jurídico-administrativa puede considerarse como políticamente neutra (supra, 1).

\subsubsection{Inutilidad cientifica}

En segundo lugar, el rechazo hacia la noción de relación jurídico-administrativa suele justificarse en su escaso o nulo potencial científico. Al margen de su falta de adecuación a las peculiaridades estructurales del Derecho público ${ }^{71}$, la figura presentaría severas deficiencias para el tratamiento teórico de un Derecho administrativo sofisticado como el actual, debido, fundamentalmente, a su simplicidad ${ }^{72}$ y a su vaguedad ${ }^{73}$.

Cabe aceptar, en efecto, que la teoría de la relación jurídico-administrativa presenta, en su estado actual, importantes deficiencias para servir como eje ordenador del sistema de Derecho administrativo. Sin embargo, ello no es una razón para el rechazo de la figura, sino una consecuencia de su prolongada desatención académica. La causa principal de la limitada utilidad científica de la perspectiva subjetiva es, precisamente, su falta de desarrollo dogmático, así como su desfase y su concepción en términos decimonónicos. Hasta ahora, la idea de relación jurídica se ha utilizado, en el mejor de los casos, como un catálogo puramente descriptivo de las situaciones jurídicosubjetivas correlativas de ciudadano y Administración ${ }^{74}$; situaciones que, por su parte, apenas han comenzado a ser objeto de renovación hasta fechas recientes ${ }^{75}$. De modo que el argumento no debería conducir al abandono de la categoría sino, antes bien, a su desarrollo y actualización. Una teoría renovada en este ámbito sería, desde luego, mucho más útil que la existente en la actualidad. Buena prueba de ello es la centralidad dogmática de aquellas partes de la aproximación subjetiva que sí han sido objeto de tratamiento y renovación científicas intensas durante los últimos años. Esto es lo que sucede, en particular, con la teoría de los derechos fundamentales, a la que se hará alusión después.

Una vez rechazada la crítica atinente a la inmadurez dogmática de la relación jurídico-administrativa, procede abordar la relativa a su vaguedad o abstracción. Es cierto que, a pesar de su omnipresencia en el lenguaje jurídico, el concepto parece carecer de contornos técnicos bien definidos ${ }^{76}$, y que suele presentarse como un amplio

71 Sobre esta inadecuación, cfr. lo expuesto en el epígrafe inmediatamente anterior.

72 MAURER, 2011, se refiere, por ejemplo, a la "inmadurez" dogmática de la noción.

73 GASCÓN Y MARÍN, 1933: 60: «el rechazar este elemento como característico del Derecho administrativo, obedece a su imprecisión más que a su incerteza»; SCHMIDT-ASSMANN, 2003: 316: «la idea de relación jurídica en sí misma y desde un punto de vista abstracto y general es demasiado vaga».

74 BAÑO LEÓN, 2018: 2.

75 MEDINA ALCOZ, 2016; VAQUER CABALLERÍA, 2016; GARCÍA-ANDRADE GÓMEZ, en prensa.

76 José Eugenio SORIANO GARCÍA, “Evolución del concepto ‘relación jurídica’ en su aplicación al Derecho público”, Revista de Administración Pública, núm. 90, 1979, pp. 33-78 (p. 33). 
campo relativamente inexplorado y precario $^{77}$; crítica esta, por cierto, que también se encuentra presente entre los cultivadores del Derecho civil ${ }^{78}$, y que en el Derecho administrativo ha recaído también, ocasionalmente, sobre la teoría de las formas de actividad de la administración ${ }^{79}$. En cualquier caso, la vaguedad de la noción de relación jurídica no es sino consecuencia, en buena medida, de la situación de desatención académica a que acaba de aludirse. Pero debe tenerse en cuenta, además, que el elevado grado de abstracción de la figura no necesariamente implica su ausencia de utilidad. A estos efectos es necesario detenerse brevemente en dos aspectos.

El primero de ellos es el relativo al rol de la perspectiva subjetiva, y por tanto de la teoría de la relación jurídica, en la construcción del sistema. Como se verá después (infra 4), en la parte general de la disciplina aquellas se encuentran llamadas a desempeñar, principalmente, una función heurística. Pues bien, en la medida en que sirva para detectar y racionalizar problemas, así como para sugerir nuevas vías de análisis de la realidad, no cabe considerar que la vaguedad de la noción de relación jurídica sea un síntoma de su imperfección. Por el contrario, tal y como se ha puesto de manifiesto recientemente en la doctrina española, el uso de conceptos con una finalidad heurística no está necesariamente vinculado a la precisión y estabilidad del significado de aquellos, sino que, por el contrario, puede requerir conceptos dotados de cierta ambigüedad y vaguedad ${ }^{80}$.

En segundo lugar, en este trabajo se sostiene la tesis de que es necesario y útil incorporar una teoría renovada de la relación jurídico-administrativa a la parte general del sistema. A ello no obsta, sin embargo, afirmar también que esta figura está llamada a desplegar su máximo potencial ordenador en un nivel de abstracción intermedio, entre el Derecho administrativo general y las regulaciones sectoriales de las que necesariamente ha de nutrirse la construcción sistemática. La característica principal de los sectores del Derecho administrativo es su atención a problemas concretos, derivados, precisamente, de la contraposición de intereses o posiciones jurídico-subjetivas subyacentes a cada uno de ellos ${ }^{81}$. La tendencia a la sectorialización o especialización del Derecho es, además, creciente en el Estado social y democrático contemporáneo, que exige atender a la composición de intereses en cada ámbito de regulación ${ }^{82}$. Una de las virtudes de la figura de la relación jurídica -también en el ámbito privado- es, precisamente, su aptitud para adaptarse a diversas manifestaciones según el sector material en cuyo seno se ubique, de manera tal que, en realidad, no existiría una

77 Peter HÄBERLE, Pluralismo y Constitución. Estudios de Teoría Constitucional de la sociedad abierta, Tecnos, Madrid, 2002, p. 227.

78 Por ejemplo, José Luis LACRUZ BERDEJO, Elementos de Derecho civil, Bosch, Barcelona, 1974 , p. 238, se refiere a la relación jurídica como "concepto general e intuitivo", falto de trascendencia, e «incapaz de producir normas».

79 Eberhard SCHMIDT-ASSMANN, "La doctrina de las formas jurídicas de la actividad administrativa. Su significado en el sistema del Derecho administrativo y para el pensamiento administrativo actual”, Documentación Administrativa, núms. 235-236, 1993, pp. 7-31 (p. 17).

80 DÍEZ SASTRE, 2018: marg. 219.

81 SCHMIDT-ASSMANN, 2003: 8.

82 VELASCO CABALLERO, 2014: 76. 
relación jurídico-administrativa, sino una multiplicidad de ellas, sujetas a diferentes regulaciones y formas ${ }^{83}$. La construcción del sistema encuentra una herramienta útil, de hecho, en la reconducción de estas manifestaciones sectoriales a modelos o tipos de relaciones jurídico-administrativas dotados de un grado intermedio de abstracción y ubicados en el segundo escalón de la parte general. Así sucede, por ejemplo, con aquellos ámbitos del Derecho administrativos que han consolidado su propia "parte general", tal como el Derecho tributario, administrativo sancionador, subvencional, expropiatorio, o de la función pública.

\subsection{Argumentos a favor}

Varias razones pueden aducirse para fundamentar la necesidad de renovación de la teoría de la relación jurídico-administrativa, así como de su incorporación a la parte general del sistema. En parte, estas razones no son sino corolarios lógicos de la pérdida de validez de los argumentos esgrimidos tradicionalmente por la ciencia del Derecho administrativo para rechazar la adecuación y utilidad de la figura como herramienta de construcción científica. Pero a ello pueden añadirse algunos argumentos de peso más. Veamos.

\subsubsection{El rol central y las recientes transformaciones de la perspectiva subjetiva}

No parece necesario insistir sobre el hecho de que, a pesar de su relativo abandono y de las reticencias hacia su uso explícito, la perspectiva subjetiva se encuentra en la base del entero Derecho administrativo y de su dogmática. Todo ordenamiento jurídicoadministrativo, en su dimensión objetiva, se ha construido históricamente (de forma más o menos expresa) sobre una determinada concepción de las situaciones jurídicas correlativas de Administración y ciudadano ${ }^{84}$. Desde esta perspectiva, resulta evidente que este ángulo de observación del Derecho administrativo no es precisamente novedoso ${ }^{85}$. El ordenamiento administrativo forjado al albor del principio de Estado de Derecho toma como una de sus premisas más elementales, precisamente, la consideración de la interacción entre Estado y ciudadano como una relación jurídica ${ }^{86}$. En efecto, el nacimiento del Derecho administrativo como rama del ordenamiento

83 MAURER, 2011: 206.

84 Así, paradigmáticamente, en los autores de la doctrina clásica alemana: Georg JELLINEK, System der subjektiven öffentlichen Rechte, Akademische Verlagsbuchhandlung von J. B. C. Mohr, Freiburg, 1982; MAYER, 1895; Walter JELLINEK, Verwaltungsrecht, Springer, Berlín, 1920; y FLEINER (1933).

85 BAUER, 1993: 150; SCHMIDT-ASSMANN, 2003: 313.

86 Eberhard SCHMIDT-ASSMANN, "Der Rechtsstaat", en Josef ISENSEE y Paul KIRCHHOF (eds.), Handbuch des Staatsrechts der Bundesrepublik Deutschland. Band I, C. F. Müller, Heidelberg, 1987, pp. 987-1044 (p. 1000). 
con sustantividad propia se produjo solo a partir del momento histórico en que el Derecho objetivo reconoció al ciudadano posiciones jurídicas activas frente al poder público y configuró a este como sujeto dotado de personalidad jurídica y sometido en su actuación al Derecho, de manera tal que Estado y ciudadano pasaron a ser concebidos como sujetos que entablaban entre sí relaciones impregnadas de juridicidad $^{87}$. Ya solo por esta razón la teoría de la relación jurídica, en tanto que instrumento teórico que permite articular el análisis en clave subjetiva, no debería ser una magnitud preterida por la ciencia del Derecho administrativo ${ }^{88}$.

Además, debido a su carácter central, cualquier modificación de los cometidos, funciones, y posiciones respectivas de Administración y ciudadano «se transmite inmediatamente, y con efectos multiplicadores, a todas las instituciones de Derecho administrativo, que, por refracción, terminan por adquirir un sentido nuevo» ${ }^{89}$. De hecho, uno de los problemas recurrentes del Derecho administrativo contemporáneo se cifra en la dificultad de adaptar su dogmática clásica a contextos caracterizados por la redefinición de las interacciones entre Estado y sociedad (por ejemplo, en el ámbito de la actividad administrativa de regulación y supervisión). Se adelanta, así, una idea sobre la que se volverá después: estos problemas solo pueden racionalizarse jurídicamente de forma adecuada si se parte de la nueva posición jurídica subjetiva de cada uno de los sujetos implicados.

La teoría de la relación jurídico-administrativa no permanece impasible en el territorio ni en el tiempo, sino que está en función de los desarrollos normativos y, más aún, del contexto político e institucional que subyace a ellos. Se encuentra condicionada por las coordenadas juridico-politicas existentes en cada momento y lugar ${ }^{90}$. Sin embargo, en España no hemos acometido aún más que parcialmente la renovación de esta parte de la disciplina a la luz de sus actuales presupuestos constitucionales y de Derecho europeo. La mera constatación del desfase de toda construcción científica es, per se, un fuerte argumento para su revisión y teorización renovada ${ }^{91}$. Y ello con independencia de la vocación, más o menos tuitiva de los intereses individuales o generales, con que esa tarea se acometa.

En un ordenamiento jurídico, como el español, en el que las decisiones básicas sobre las posiciones recíprocas de ciudadano y Administración se encuentran fijadas en el máximo nivel normativo, y donde su desarrollo y concreción están llamados a producirse en virtud del funcionamiento del sistema democrático, la revisión de la teoria de la relación jurídico-administrativa no puede realizarse desde una perspectiva ontológica en sentido estricto. Quiere decirse con ello que no se trata aquí de utilizar la

87 ROYO-VILLANOVA, 1964: 84.

88 SCHMIDT-ASSMANN, 1993: 26; BAUER, 1993: 152.

89 Javier BARNÉS VÁZQUEZ, "La transposición de valores públicos a los agentes privados por medio de elementos de organización y de procedimiento", en Mercé DARNACULLETA, José ESTEVE PARDO e Indra SPIECKER (eds.), Estrategias del Derecho ante la incertidumbre y la globalización, Marcial Pons, Madrid, 2015, pp. 281-311 (p. 282).

90 MEDINA ALCOZ, 2016.

91 BACHOF, 1972: 218. 
teoría de la relación jurídico-administrativa para abogar por un Derecho administrativo más protector del individuo (es decir, más liberal), pues esta es una cuestión que no corresponde a la ciencia del Derecho administrativo sino a la política (cfr. supra, 1). Una vez los elementos básicos de las posiciones correlativas de Administración y sujetos privados han sido fijadas a nivel constitucional (europeo e interno), no cabe atribuir ya a la teoría de la relación jurídica la función política-petrificadora del statu $q u o-$ con que en su momento surgió en el seno del Derecho privado ${ }^{92}$.

Lo verdaderamente relevante no consiste en optar por un Derecho administrativo explicado en un lenguaje objetivo o subjetivo. La dicotomía es, a mi juicio, artificiosa, si se interpreta como separación rígida: ambas perspectivas son complementarias en tanto que formas de contemplación de una misma realidad. Lo importante es racionalizar teóricamente la aproximación subjetiva al Derecho administrativo, de tal manera que sea capaz de transmitir sus fundamentos constitucionales a la dogmática objetiva y, a la vez, sea útil como instrumento para la interpretación y aplicación de esta, así como para su permanente revisión y actualización.

En este sentido, el punto de partida ha de ser la transformación de las posiciones de ciudadano y Administración, que no se corresponden ya con las propias de la teoría de la relación jurídica forjada durante las primeras etapas históricas del Derecho administrativo. Sin embargo, de modo inercial, continuamos en buena medida utilizando esa teoría clásica de manera más o menos implícita, sin revisar de manera completa su significado, y sin caer suficientemente en la cuenta de que aquella condiciona decisivamente el modo en que se formaliza y transmite el conocimiento entre los miembros de la comunidad científica ${ }^{93}$. A pesar de que el Estado constitucional y el Derecho internacional y europeo de los derechos humanos han impulsado la contemplación en clave subjetiva del Derecho administrativo, la dogmática de la disciplina está encontrando dificultades de adaptación debido al lastre de las elaboraciones técnicas de la doctrina clásica, condicionadas por el marco jurídico autoritario procedente del pasado ${ }^{94}$.

Del lado del ciudadano, la opción constitucional por la dignidad humana como fundamento del orden político y de la paz social (art. 10.1 CE) ha supuesto la superación de la antigua figura del súbdito y su sustitución por la del ciudadano activo ${ }^{95}$, que participa en la definición y satisfacción del interés general (Estado democrático), cuyas posiciones jurídicas son merecedoras de tutela judicial plena (Estado de Derecho), pero que puede ser legítimamente instrumentalizado en favor del colectivo

92 Acerca de los peligros del pensamiento institucional en la dogmática jurídica, DÍEZ SASTRE, 2018: marg. 171 ss.

93 DÍEZ SASTRE, 2018: marg. 54, citando a Thomas S. KUHN, La estructura de las revoluciones cientificas, 4. ${ }^{\mathrm{a}}$ reimp., Fondo de Cultura Económica, México D. F., 2012 [trad. de Carlos Solís], pp. 117 ss.

94 MEDINA ALCOZ, 2016: 96-97.

95 Peter HÄBERLE, "Die Menschenwürde als Grundlage der staatlichen Gemeinschaft", en J. ISENSEE y P. KIRCHHOF (eds.), Handbuch des Staatsrechts der Bundesrepublik Deutschland. Band I, C. F. Müller, Heidelberg, 1987, pp. 815-862 (p. 842). 
siempre y cuando se respeten ciertos límites, y, en particular, siempre que se ponderen todos los intereses en juego y se satisfagan en la medida de lo posible (Estado social). Frente a la consideración del individuo como mero objeto pasivo de la actuación administrativa, merecedor -en el mejor de los casos- de defensa frente a ella, el nuevo marco constitucional y europeo ha ampliado la perspectiva para configurar al ciudadano como sujeto activo y corresponsable ${ }^{96}$. Ello conduce irremisiblemente a la necesidad de repensar categorías subjetivas heredadas, como -en particular- la del deber en sentido técnico, la del interés legítimo o la del derecho público subjetivo. Además, y a pesar de no reconocer derechos subjetivos judicialmente actuables de forma directa, el denso contenido social de los principios rectores recogidos en los arts. 39 a $52 \mathrm{CE}$ ha contribuido también a fomentar la perspectiva subjetiva en el Derecho administrativo español, en la medida en que impone a todos los poderes públicos el deber de tomar en consideración las especiales necesidades de protección de determinados colectivos, como los hijos menores y madres (art. $39 \mathrm{CE}$ ), los jóvenes (art. $48 \mathrm{CE}$ ), los minusválidos (art. $49 \mathrm{CE}$ ), los ancianos (art. $50 \mathrm{CE}$ ), o los consumidores y usuarios (art. $51 \mathrm{CE})^{97}$.

Mención especial merece aquí la consagración constitucional de los derechos fundamentales y en particular, por su repercusión sobre el Derecho administrativo, el reconocimiento de su dimensión objetiva. Al precisar que los derechos fundamentales no son solo derechos subjetivos de los ciudadanos, sino también valores objetivos que irradian el ordenamiento en su conjunto, la llamada vertiente objetiva de los derechos fundamentales ha contribuido a la aproximación en clave subjetiva al Derecho administrativo, pues imponer sobre los poderes público deberes juridicos de protección que derivan directamente de la norma constitucional ${ }^{9}$. Como es sabido, una de las principales consecuencias de esta aproximación -consolidada a partir de la Sentencia Lüth en Alemania ${ }^{99}$, y de la STC 53/1985 en España ${ }^{100}$ - ha sido la "acreditación» de la organización y el procedimiento administrativo como medios directos para la realización y garantía de los derechos fundamentales, así como para «compensar posiciones constitucionales encontradas» ${ }^{101}$. Con ello, organización y procedimiento han pasado a quedar inextricablemente vinculados a las situaciones jurídico-subjetivas sobre las que se proyectan, dejando de ser únicamente mecanismos que facilitan y ordenan la actuación y el control de la Administración.

El ordenamiento de la Unión presiona también a favor de la aproximación subjetiva al Derecho, por más que, en el seno de aquel, resulte evidente el predominio de una lógica utilitarista, centrada más en asegurar el efectivo cumplimiento de las

96 BARNÉS VÁZQUEZ, 2015: 284 ss., 294.

97 RODRÍGUEZ DE SANTIAGO, 2007: 32.

98 Miguel A. PRESNO LINERA, "La estructura de las normas de derechos fundamentales", en Francisco J. BASTIDA FREIJEDO et al., Teoría general de los derechos fundamentales en la Constitución Española de 1978, Tecnos, Madrid, 2004, pp. 45-56.

99 BVerfGE 7, 198 (I. Senate).

100 STC 53/1985, de 11 de abril, relativa a la despenalización parcial del aborto.

101 Konrad HESSE, Derecho constitucional y Derecho privado, Civitas, Madrid, 1995. 
normas europeas que en perfilar el rol de individuos y empresas como fin en sí mismo ${ }^{102}$. En efecto, el punto de partida del Derecho europeo no se encuentra en las distintas posiciones de poder público y sujetos privados, a quienes a menudo trata de forma indistinta. Su interés prioritario no consiste en garantizar la protección de los segundos frente al primero, sino en asegurar la consecución de determinados objetivos de interés público, de carácter principalmente económico. Por este motivo, ni el ordenamiento de la Unión ni la literatura académica han desarrollado aún de manera completa el estatus del ciudadano europeo ni sus relaciones con el poder público ${ }^{103}$. A pesar de ello, el Derecho de la Unión Europea ha transformado de forma resuelta la posición juridica de los sujetos privados (ciudadanos y empresas) y la ha convertido en uno de sus elementos centrales. Dos factores son especialmente relevantes para entender este desarrollo.

El primero de ellos es la fuerza legitimadora del lenguaje de los derechos. Frente al motor económico de la integración europea, el reconocimiento de derechos y libertades fundamentales (en última instancia, a través de la Carta de Derechos Fundamentales de la Unión) dota al proyecto europeo de cierto contenido moral, indispensable para su aceptación por la ciudadanía ${ }^{104}$. Esta función legitimadora se adivina también tras el reconocimiento de derechos de participación ciudadana en los procedimientos de elaboración de normas europeas ${ }^{105}$.

El segundo factor, y probablemente el más decisivo, es el de la fuerza integradora de la lengua de los derechos. Desde la perspectiva de la aplicación centralizada del Derecho europeo, la existencia de un catálogo de derechos individuales se traduce en el aumento de poder de la jurisdicción comunitaria frente a las nacionales, que pierden la capacidad de oponer sus propias cartas iusfundamentales como justificación para el incumplimiento de las normas de la Unión. En el ámbito de la aplicación descentralizada del Derecho europeo, la idea de efectividad es crucial debido al «déficit institucional» de la Unión, que reduce su capacidad de investigación y, por ende, aumenta el riesgo de infraejecución normativa ${ }^{106}$. Aquí, el mecanismo de la llamada «subjetivación funcional» ${ }^{107}$ ha desplegado efectos formidables, en conexión con la figura del efecto directo, como instrumento para asegurar la efectividad de las normas europeas ${ }^{108}$. Desde Van Gend en Loos, la consideración de las obligaciones objetivas impuestas por el Derecho europeo como derechos individuales correlativos de

102 SCHMIDT-ASSMANN, 2003: 45-56.

103 MASING, 2012: 481 ss.

104 Gráinne DE BÚRCA, "The language of rights and European integration”, en Jo SHAW y Gillian MORE (eds.), New Legal Dynamics of European Union, Oxford University Press, Oxford, 1996.

105 Sobre ello, MENDES, 2011: 192 ss.; Joana MENDES, "Rule of law and participation: a normative analysis of internationalized rulemaking as composite procedures", International Journal of Constitutional Law, vol. 12, núm. 2, 2014, pp. 370-401.

106 Fernando PASTOR-MERCHANTE, The Role of Competitors in the Enforcement of State Aid Law, Hart Publishing, Londres, 2017, p. 36.

107 Miguel POIARES MADURO, We the Court: The European Court of Justice and the European Economic Constitution, Hart Publishing, Oxford, 1998, p. 9.

108 HOFMANN y WARIN, 2017. 
los ciudadanos y empresas ha supuesto concebir a estos como guardianes del efectivo cumplimiento de la normativa comunitaria ${ }^{109}$. De esta manera, el Derecho europeo permite la introducción de sofisticados mecanismos de "aplicación privada» de sus normas y, con ello, exige ampliar la perspectiva a nuevas estrategias regulatorias en cuyo marco ciudadanos y empresas dejan de ser considerados como meros objetos pasivos de la actuación de la Unión ${ }^{110}$. Tales sujetos pasan así a erigirse en actores decisivos para asegurar el cumplimiento de los objetivos europeos ${ }^{111}$, de un modo que la aplicación centralizada a través de la Comisión como "guardiana de los Tratados" no permitiría ${ }^{112}$. Por lo demás, el carácter complejo de la Administración europea, entendida en sentido amplio, impulsa el foco hacia las relaciones jurídicas multipolares (al menos, hacia aquellas en que participa alguna institución, órgano u organismo europeo, alguna/s autoridad/es nacional/es, y uno o varios particulares o empresas).

En síntesis, la conjunción de estas líneas de desarrollo -y, en particular, la derivación de posiciones activas a partir de las obligaciones impuestas por el Derecho objetivo-, está contribuyendo de manera decisiva a la recuperación del interés por el análisis en clave subjetiva de los ordenamientos administrativos nacionales 113, asi como a la transformación de los conceptos elementales que explican la posición jurídico-subjetiva correlativa de Administración y ciudadano. Esta evolución no resulta tan evidente en Espańa como en otros Estados miembros que tradicionalmente habían acogido un concepto estrecho de derecho público subjetivo. Así sucede, en particular, en Alemania y en Austria. Allí, la ampliación del concepto de derecho individual inducida por el mecanismo de la «subjetivación funcional» está provocando, desde hace ya décadas, una intensa revisión de la teoría de la norma tuitiva (Schutznormtheorie) ${ }^{114}$, sobre

109 STJCE de 5 de febrero de 1963, as. 26-62, NV Algemene Transport-en Expeditie Onderneming van Gend \& Loos contra Administración fiscal holandesa [ECLI:EU:C:1963:1].

110 Richard RAWLINGS, "Engaged elites: Citizen Action and Institutional Attitudes in Commission Enforcement", European Law Journal, vol. 6, núm. 1, 2000, pp. 4-28; Adam TOMKINS, "Of Institutions and Individuals: The Enforcement of EC Law", en Paul CRAIG y Richard RAWLINGS (eds.), Law and Administration in Europe - Essays in Honour of Carol Harlow, Oxford University Press, Oxford, 2003, pp. 273-295. Sobre este tipo de estrategias, en general, Jody FREEMAN, "The Private Role in Public Governance", New York University Law Review, vol. 75, núm. 3, 2000, pp. 543-675.

111 Bruno DE WITTE, "Direct Effect, Primacy, and the Nature of the Legal Order", en P. CRAIG y G. DE BÚRCA (eds.), The Evolution of EU Law, 2a ed., Oxford University Press, Oxford, 2011, pp. 323-362 (p. 358); Joseph H. H. WEILER, "Van Ge nd en Loos: The individual as subject and object and the dilemma (p. 96).

112 Matthias RUFFERT, "Rights and Remedies in European Community Law: a Comparative View”, Common Market Law Review, vol. 34, núm. 2, 1997, pp. 307-336 (p. 327).

113 Ferdinand WOLLENSCHLÄGER, "Constitutionalisation and deconstitutionalisation of administrative law in view of Europeanisation and emancipation", Review of European Administrative Law, vol. 10, núm. 1, 2017, pp. 7-79 (p. 47).

${ }_{114}$ Johannes MASING, Die Mobilisierung des Bürgers für die Durchsetzung des Rechts. Europäische Impulse für eine Revision der Lehre vom subjektiv-öffentlichen Recht, Duncker \& Humblot, Berlín, 1997; Christian CALLIES, "Kohärenz und Konvergenz beim europäischen Individualrechtsschutz Der Zugang zum Gericht im Lichte des Grundrechts auf effektiven Recthsschutz", Neue Juristische Wochenschrift, núm. 49, 2002, pp. 3577-3582; Mathias HONG, "Subjektive Rechte und Schutznormtheorie im europäischen Verwaltungsraum”, Juristen Zeitung, núm. 8, 2012, pp. 380-388; Helge- 
la cual la doctrina clásica había edificado el concepto de derecho público subjetivo y el entero sistema de justicia administrativa. Una transformación similar, pero de mayor intensidad aún, cabe observar en Francia, con el paso de la jurisdicción objetiva a un sistema de justicia administrativa subjetivado por impulso, entre otros factores, del Derecho de la Unión ${ }^{115}$.

También la posición de la Administración se ha visto sometida a una intensa transformación por influjo de la Constitución, y, posteriormente, del Derecho europeo y de la globalización. Estos fenómenos han conducido a la apertura de la Administración en sentido vertical (debido al traspaso de poder a entes supra e infra estatales) y en sentido horizontal (por la dilución de su contraposición al ciudadano). Ello ha contribuido a difuminar la separación entre Estado y sociedad, así como entre interés público y privado. La Administración es ahora una institución dotada de legitimación democrática indirecta, que se encuentra sometida a los mandatos de transparencia y participación, y que está enfocada a la satisfacción de intereses generales complejos y contrapuestos, tarea esta en la que está llamada a colaborar con la sociedad. La responsabilidad estatal en el cumplimiento de sus fines puede adoptar ahora diversas fórmulas, cuyos extremos ideales son la mera intervención normativa, sin previsión de ulterior actuación administrativa (Rahmenverantwortung), hasta la plena ejecución de tareas públicas a través de la Administración (Erfüllungsverantwortung) ${ }^{116}$.

Entre otras consecuencias, estos fenómenos han conducido a una disminución de la capacidad de dirección legislativa de la actividad de la Administración, y a un correlativo aumento de la discrecionalidad y flexibilidad en la acción de esta; al traspaso de la titularidad de funciones tradicionalmente públicas a actores privados, con la consiguiente aparición de nuevos tipos de actividad administrativa y de la extensión del ámbito de aplicación de las normas de Derecho público ${ }^{117}$; a la pérdida de centralidad de la actividad unilateral de la Administración, en beneficio de fórmulas de actuación negociadas y colaborativas ${ }^{118}$; y a la creciente intervención administrativa sobre constelaciones de intereses públicos y privados contrapuestos, con el subsiguiente desplazamiento de la clásica relación bilateral Estado-ciudadano por relaciones jurídicas de carácter multipolar ${ }^{119}$.

Marten VOIGTS, Die Subjektivierung von Gemeinwohlinteressen als Demokratisierung der Verwaltung, LIT Verlag, Münster, 2016.

115 Mitchel de S.-O.-l'E. LASSER, Judicial Transformations: The Rights Revolution in the Courts of Europe, Oxford University Press, Oxford, 2009; Jean SIRINELLI, "La subjectivisation du recours pour excès de pouvoir", Revue Française de Droit Administratif, núm. 3, 2016, pp. 529-544.

116 SCHMIDT-ASSMANN, 2003: 186-188.

117 José ESTEVE PARDO, "La extensión del Derecho público. Una reacción necesaria", Revista de Administración Pública, núm. 189, 2012, pp. 11-40; José ESTEVE PARDO, La nueva relación entre Estado y sociedad. Aproximación al trasfondo de la crisis, Marcial Pons, Madrid, 2013.

118 BAUER, 1993: 137; Santiago MUÑOZ MACHADO, Tratado de Derecho Administrativo y Derecho Público General. Tomo I. Historia de las Instituciones Jurídico-administrativas-1, Ed. BOE, Madrid, 2015, p. 61.

119 Sabino CASSESE, Giulio NAPOLITANO y Lorenzo CASINI, "Towards multipolar administrative law: A theoretical perspective", International Journal of Constitutional Law, vol. 12, núm. 2, 2014, pp. 354-356. 
Hasta hace unas décadas, la dogmática del Derecho administrativo había prestado atención casi exclusiva a la actividad de la Administración, a partir del dato de su neta separación de la sociedad. La erosión de esa línea divisoria y su transformación en un territorio de encuentros y colaboración exige tener ahora en cuenta, también desde esta perspectiva, a los sujetos privados ${ }^{120}$. Creo que es necesario profundizar aún algo más en esta idea. La configuración que de Estado y ciudadano realizan la Constitución y el Derecho europeo exige prestar atención a este y a su protección como fin en si mismo. Pero, además de ello, la ausencia de un monopolio estatal en la satisfacción del interés general exige concebir al individuo y a los grupos en que se integra, también, como sujetos activos, al menos en dos sentidos.

Por una parte, el Derecho positivo está produciendo una creciente desvinculación entre control judicial y tutela individual, pero con una orientación netamente contrapuesta a la de épocas precedentes: cada vez más, se abre al sector privado la posibilidad de activar los mecanismos de control judicial frente a actividades en las que no están en juego situaciones jurídicas individuales, sino intereses colectivos. Así se desprende de la expansión de la acción pública o popular, desde sus tradicionales dominios (el urbanismo y el medio ambiente) hasta nuevos ámbitos [consumo, vivienda, etc.; cfr. en general el art. 19.1.b) LJCA].

De otro lado, las normas de Derecho administrativo crecientemente contemplan a los particulares como sujetos susceptibles de dirección y control, en la medida en que estos participen activamente en distintos tramos del ciclo circular de las políticas públicas (fijación de estándares o normas, seguimiento, vigilancia o certificación de su cumplimiento, prestación de servicios de interés general, etc.) ${ }^{121}$. En otras palabras: incluso si se contemplan desde la exclusiva perspectiva del interés general, el Derecho administrativo y su ciencia no pueden mirar ya unicamente a la Administración, porque ya no es solamente ella quien desempeña funciones de carácter materialmente administrativo. Ante el traspaso al sector privado de la titularidad de funciones de relevancia pública y, por lo tanto, la necesidad de racionalizar jurídicamente su actuación en términos más o menos análogos a los de las organizaciones administrativas tradicionales, el Derecho administrativo contemporáneo no puede prescindir de la idea de relación jurídica, máxime cuando el diseño del régimen jurídico de estos sujetos está llamado a combinar y a equilibrar elementos propios del régimen de las Administraciones y de los particulares.

\subsubsection{Las carencias de la perspectiva objetiva}

En el apartado anterior se ha mantenido que la aproximación en clave subjetiva juega un papel central en el Derecho administrativo y en su tratamiento científico. Se intentará ahora justificar que, además, ese papel es aún más relevante en la medida

120 BARNÉS VÁZQUEZ, 2015: 282 ss.

121 BARNÉS VÁZQUEZ, 2015: 283-284. 
en que, en su configuración actual, la aproximación en clave objetiva a esta rama del ordenamiento presenta graves deficiencias, a cuya superación puede contribuir el uso instrumental de la teoria de la relación jurídico-administrativa.

En esencia, la dogmática contemporánea del Derecho administrativo se presenta como una doctrina de las formas (y, secundariamente, de los tipos) de actividad de la Administración. Los contornos fundamentales de esta construcción teórica quedaron forjados durante el siglo XIX a la luz de ciertos sectores de referencia caracterizados por la simplicidad, bipolaridad, y carácter finito de las relaciones jurídicas subyacentes. En efecto, el núcleo de dicha doctrina, conformado por la actuación unilateral en forma de actos administrativos, tomó como punto de partida la necesidad de defensa de la libertad del ciudadano frente a intervenciones públicas limitadoras o restrictivas. La obra de Otto Mayer representa la culminación de este proceso, caracterizado por la ubicación del acto administrativo en el centro del sistema y la configuración de este conforme al modelo del Derecho de policía ${ }^{122}$. Aunque, no mucho después, esta construcción inicial fue objeto de ampliaciones y ajustes para dar entrada también a otros tipos de actuación administrativa (en un primer momento, fomento y prestación), la doctrina de las formas sigue estando impregnada, hasta hoy, de esa caracterización defensiva y bilateral ${ }^{123}$. Las formas jurídicas han llegado hasta nosotros como clave de bóveda del sistema de protección del individuo, pues con ellas se obstaculiza la arbitrariedad y se ofrecen puntos de conexión operativos para la tutela judicial, al tiempo que su función de depósito satisface exigencias elementales de seguridad jurídica ${ }^{124}$.

Durante largo tiempo, los juristas de la Europa continental encontraron en esa construcción dogmática tradicional un instrumento de ordenación óptimo para racionalizar y explicar el sistema de Derecho administrativo. Sin embargo, la consolidación de la teoría de las formas y su potente vis estética han conducido, con el tiempo, a una relegación de la relación jurídico-administrativa como ángulo alternativo de observación de esa misma realidad jurídica ${ }^{125}$. Además, la progresiva desvinculación entre la sustancia (relación jurídica) y la construcción dogmática objetiva (teoría de las formas y de los tipos de Administración), provocada por el paradigma autoritario vigente en Europa hasta mediados del siglo $\mathrm{xx}$, ha conducido a una petrificación de la dogmática objetiva del Derecho administrativo, que presenta severas dificultades para adaptarse a los nuevos fenómenos regulados por esta rama del ordenamiento. Y la causa principal de ello es, precisamente, que las relaciones jurídicas subyacentes a estos nuevos fenómenos son muy distintas a las que sirvieron de base a la doctrina objetiva tradicional ${ }^{126}$. Por ello, la renovación de la teoría de la relación jurídico-adminis-

122 Wolfgang MEYER-HESEMANN, "Die paradigmatische Bedeutung Otto Mayers für die Entwicklung der deutschen Verewaltungsrechtswissenschaft”, Rechtstheorie, núm. 13, 1982, pp. 496-502.

123 De ello es expresiva, por ejemplo, la regulación general contemporánea del procedimiento administrativo: al respecto, BARNÉS VÁZQUEZ, 2008: 20.

124 BAUER, 1993: 143.

125 DÍEZ SASTRE, 2018: marg. 55.

126 SÁNCHEZ MORÓN, 2018: 18. 
trativa supone un paso irrenunciable para acometer la reconstrucción científica de la disciplina de manera sistemática, sin que resulte suficiente, con carácter general, la introducción de ajustes, matizaciones y excepciones ad hoc a las teorías formales que se formaron sobre unas premisas jurídico-subjetivas netamente distintas a las actuales ${ }^{127}$.

Las deficiencias de la dogmática objetiva heredada como marco de ordenación del Derecho administrativo contemporáneo resultan, en primer lugar, de su desarrollo asimétrico. La atención excesiva sobre la figura del acto administrativo (y, en menor medida, del reglamento y el contrato) ha conducido a la insuficiente elaboración doctrinal de ciertas actividades administrativas, como las materiales o informales, que se presentan en la construcción científica actual como una categoría residual carente de perfiles jurídicos bien definidos ${ }^{128}$. El infradesarrollo de la dogmática objetiva allí donde la actuación administrativa formal plasmada en actos desaparece o disminuye su presencia (caso, por ejemplo, de la sustitución de las autorizaciones por comunicaciones previas, o de la actuación material de la Administración en el ámbito de las prestaciones sanitarias) conlleva, a su vez, la reducción o supresión de los mecanismos de protección de las posiciones subjetivas afectadas, debido a la tradicional ligazón de estos con la teoría de las formas.

Así sucede, por ejemplo, con el procedimiento administrativo. Su fuerte dependencia tradicional de la figura del acto como forma de actuación de la Administración ha obstaculizado durante largo tiempo el desarrollo de un modelo de procedimiento administrativo de la prestación material, a pesar de que este tipo de actividad administrativa se proyecta, a veces, sobre ámbitos en los existen deberes constitucionales de protección a través de la organización y del procedimiento administrativo $^{129}$.

Asimismo, las carencias de la dogmática objetiva heredada derivan de su carácter autorreferencial, esto es, de su interés exclusivo por la actividad de la Administración y su control, con la consiguiente postergación de otros bienes jurídicos en juego. Solo durante las últimas décadas, y por efecto principalmente del juego de los derechos fundamentales, la dogmática tradicional ha comenzado a ser modificada a través de la incorporación de elementos que permiten percibir y resolver dogmáticamente algunas de las posiciones subjetivas del ciudadano. Así sucede, en particular, con los recién mencionados deberes de protección de las posiciones subjetivas a través de la organización y el procedimiento. Sin embargo, el nivel de adaptación alcanzado es netamente insuficiente, por atender todavía en exceso a la posición de la Administración, y bastante menos a la del resto de sujetos afectados por su actividad.

Buena muestra de ello son los problemas que plantean las figuras de las comunicaciones previas y las declaraciones responsables tras la transposición de la Directiva de Servicios. En este ámbito,

127 En sentido similar, Miguel SÁNCHEZ MORÓN, La participación del ciudadano en la Administración pública, Centro de Estudios Constitucionales, Madrid, 1980, p. 18.

128 Peter KRAUSE, Rechtsformen des Verwaltungshandelns. Überlegungen zu einem System der Handlungsformen der Verwaltung, mit Ausnahme der Rechtsetzung, Duncker \& Humblot, Berlín, 1974, pp. 14 ss.

129 RODRÍGUEZ DE SANTIAGO, 2009: 1, 49, 120. 
el legislador se ha concentrado en redefinir los parámetros que gobiernan la actividad administrativa, buscando incrementar su eficiencia, sin realizar una ponderación suficiente de otros intereses públicos y privados en juego ${ }^{130}$. Desde esta segunda perspectiva, resulta insatisfactorio el tratamiento propinado a la posición de los particulares implicados: el sujeto a quien se atribuye el poder de autocontrolarse (que queda sometido sine die al riesgo de revocación de su situación) y los posibles perjudicados por el desarrollo de la actividad de aquel (cuya protección disminuye ostensiblemente, al desaparecer el procedimiento de control ex ante al que tradicionalmente se ha ligado su tutela) ${ }^{131}$.

En tercer lugar, la estructura bipolar de la dogmática objetiva tradicional hace que esta presente dificultades para la aprehensión del Derecho administrativo actual. La doctrina de las formas y de los tipos de actividad administrativa y, en particular, las construcciones teóricas clásicas relativas al acto y al procedimiento, se centran de manera casi exclusiva en la relación bipolar -entre Administración y un ciudadano, o varios ciudadanos con intereses coincidentes-, relegando a los demás sujetos afectados, en el mejor de los casos, a la consideración de terceros, dotados de menor protección y con ruptura del principio de igualdad. Ciertamente, la doctrina objetiva ha intentado incorporar dogmáticamente la tendencia a la multipolaridad mediante ajustes parciales, como por ejemplo el desarrollo del acto administrativo con doble efecto. Pero se trata de remedios puntuales que no obstan a que la teoría formal heredada obstaculice el acceso directo a las nuevas y complejas constelaciones jurídicomateriales subyacentes ${ }^{132}$.

Un ejemplo ilustrativo de estas carencias lo constituye el régimen jurídico de la adjudicación administrativa de derechos limitados en número ${ }^{133}$. En este ámbito, la relación jurídica de concurrencia subyacente a la actividad administrativa debe traducirse en específicas salvaguardias relativas a la configuración normativa del programa de adjudicación, al procedimiento y al acto a través del cual este se implementa ${ }^{134}$, así como a los mecanismos de tutela de los licitadores ${ }^{135}$. Sin embargo, la introducción de estas especificidades encuentra cierta resistencia en el Derecho positivo y en su dogmática, excesivamente imbuidos aún de la lógica de la relación jurídica bipolar.

Por último, la doctrina de las formas presenta también dificultades para captar la dimensión temporal de los fenómenos jurídicos ${ }^{136}$. Las decisiones administrativas cons-

130 Marcos VAQUER CABALLERÍA, "El criterio de la eficiencia en el Derecho administrativo", Revista de Administración Pública, núm. 186, 2011, pp. 91-135 (pp. 113-121).

131 BAÑO LEÓN, 2018.

132 BAUER, 1993: 147-148.

133 Dolores UTRILLA FERNÁNDEZ-BERMEJO, "La adjudicación administrativa de recursos escasos”, en Luis ARROYO JIMÉNEZ y Dolores UTRILLA FERNÁNDEZ-BERMEJO (dirs.), La adjudicación administrativa de recursos escasos. Ordenación sectorial y reconstrucción sistemática, Tirant lo Blanch, Valencia, 2018, pp. 25-40.

134 Ferdinand WOLLENSCHLÄGER, "El procedimiento administrativo de adjudicación de derechos limitados en número en el Derecho administrativo general”, en Luis ARROYO JIMÉNEZ y Dolores UTRILLA FERNÁNDEZ-BERMEJO (dirs.), La administración de la escasez. Los fundamentos de la actividad administrativa de adjudicación de derechos limitados en número, Marcial Pons, Madrid, 2015, pp. 139-203; Luis ARROYO JIMÉNEZ, "La adjudicación administrativa de recursos escasos", InDret, Revista para el Análisis del Derecho, núm. 1, 2015.

135 DÍEZ SASTRE, 2012; DÍEZ SASTRE, 2015.

136 BAUER, 1993: 147. 
tituyen imágenes instantáneas y estáticas en el contexto de relaciones jurídicas en curso de desarrollo y, por ello, se refieren solo a aspectos parciales de esa relación más amplia y dinámica ${ }^{137}$. Ciertamente, las formas -especialmente el acto administrativo- sirven para aprehender el instante decisivo de la relación jurídica, el punto temporal en el que el contenido de esta se fija y se define para el futuro ${ }^{138}$. Son puntos de cristalización aptos para vincularles consecuencias sistémicas fijas ${ }^{139}$. Pero, para ello, es necesario tomar en consideración la existencia y coordenadas normativas de la relación jurídica de base.

Aquí puede tomarse como ejemplo la regulación general vigente de la expropiación forzosa. La decisión administrativa de expropiar, plasmada en el acto de declaración de necesidad de ocupación, parece ser ajena a la relación jurídica subyacente entre Administración, expropiado y beneficiario. Por ello, no suele contener precisiones acerca de cuál será el contenido exacto de las posiciones subjetivas surgidas en virtud de la expropiación, ni prevé mecanismos dirigidos a garantizar su observancia, ni fija las consecuencias que conllevará su incumplimiento. La experiencia de los últimos años pone de manifiesto los graves problemas que este déficit regulatorio plantea tanto para la protección de los expropiados, como para la eficacia de la actuación administrativa expropiatoria ${ }^{140}$.

\section{AGENDA DE INVESTIGACIÓN: ELEMENTOS ESTRUCTURALES Y METODOLÓGICOS}

\subsection{Planteamiento}

A continuación se identifican algunos de los elementos centrales de una agenda de investigación dirigida a la reconstrucción y actualización de la teoría de la relación jurídico-administrativa como instrumento propio de la parte general del sistema de Derecho administrativo. En primer lugar, se propone que esta tarea debe realizarse en dos etapas o niveles de abstracción distintos, uno superior y uno intermedio -esto es, a medio camino entre la parte general y la parte especial- (infra 4.2). En segundo lugar, se mantiene que, en cada uno de esos niveles, la reformulación de la teoría debe realizarse atendiendo prioritariamente a sus funciones, que están llamadas a desplegarse con intensidad variable en cada uno de los citados niveles de abstracción (infra 4.3). Por último, esta tarea ha de realizarse a partir de la ordenación e integración sistemática de elementos normativos, jurisprudenciales y doctrinales provenientes tanto del Derecho de alcance general (constitucional, europeo, administrativo o incluso, subsidiariamente, de otras ramas del ordenamiento) como del Derecho sectorial (infra 4.4).

\footnotetext{
137 BACHOF, 1972: 231.

138 MAURER, 2011: 207.

139 SCHMIDT-ASSMANN, 1993: 9.

140 UTRILLA FERNÁNDEZ-BERMEJO, 2015.
} 


\subsection{Estructura}

\subsubsection{Nivel superior del sistema}

El primero de los elementos estructurales necesarios para incorporar adecuadamente la teoría de la relación jurídico-administrativa al nivel superior de abstracción del sistema consiste en la delimitación de su concepto, así como en su diferenciación de otras figuras u ideas más o menos cercanas. Lógicamente, el concepto de relación jurídico-administrativa que se maneje en este primer nivel de abstracción habrá de tener el menor contenido (intensión) y el mayor ámbito de aplicación (extensión), de manera tal que se permita su ulterior división en tipos, así como su concreción -en un nivel de abstracción intermedio- en relaciones jurídico-administrativas de mayor intensión y menor extensión, y por lo tanto dotadas de una mayor carga dogmática ${ }^{141}$. Según esta perspectiva, la formulación del concepto general de relación jurídico-administrativa debe abrir el ángulo de análisis a fenómenos que hasta ahora habían quedado excluidos de la definición de aquella. Además, el concepto ha de ser lo suficientemente extenso como para operar a modo de supraconcepto unitario (Oberbegriff) bajo cuya órbita pueda encontrar acogida el ulterior desarrollo sistemático de distintos fragmentos o bloques de la teoría de la relación jurídicoadministrativa, con inclusión también de las relaciones administrativas internas y de las que se producen entre distintas Administraciones públicas.

En segundo lugar, una teoría general de la relación jurídico-administrativa debe comprender el aislamiento de sus tipos atendiendo a criterios diversos. La dogmática tradicional diferenciaba, básicamente, entre relaciones de sujeción general y de sujeción especial ${ }^{142}$. La revisión de esta parte del sistema ha de replantear la utilidad, el fundamento y el alcance de dicha distinción y, además, incorporar la diferenciación entre relaciones jurídicas materiales y procedimentales, así como entre relaciones jurídicas bipolares y multipolares. Como se verá después (infra 4.5), tanto las relaciones jurídicas "meramente" materiales -esto es, carentes de plasmación procedimentalcomo las multipolares -especialmente novedosas desde el punto de vista de la dogmática tradicional- encuentran una presencia particularmente acusada en distintos ámbitos del Derecho administrativo sectorial vigente y precisan, por ello, ser debidamente decantadas y teorizadas en la parte general del sistema.

Por último, el nivel superior de abstracción de la teoría debe comprender también el tratamiento y actualización tanto de sus posibles contenidos (observación estática), esto es, de las posibles situaciones subjetivas en que pueden encontrarse recíprocamente los sujetos que de ella forman parte, como de sus fases (observación dinámica), esto es, de sus mecanismos de nacimiento, desarrollo y extinción.

141 DÍEZ SASTRE, 2018: marg. 50.

142 Sobre esta distinción, por todos, Mariano LÓPEZ BENÍTEZ, Naturaleza y presupuestos constitucionales de las relaciones especiales de sujeción, Civitas-Universidad de Córdoba, Madrid, 1994. 


\subsubsection{Nivel intermedio del sistema}

Con toda probabilidad, el mayor reto de una teoría renovada de la relación jurídico-administrativa como parte del sistema de Derecho administrativo general radica en el aislamiento y diseño, en un nivel de abstracción intermedio, de modelos o tipos de relaciones jurídico-administrativas que puedan ser útiles, tanto en el plano dogmático como regulatorio, para ordenar el ejercicio de funciones administrativas caracteristicas. La formulación de un concepto general de relación jurídico-administrativa, así como la diferenciación de sus posibles tipos abstractos y el desarrollo teórico de sus componentes estáticos y dinámicos, está llamada a actuar como paso previo para el diseño de estos modelos intermedios.

Tales modelos habrán de ser formulados a la luz de cómo se componen los intereses y las posiciones subjetivas de los sujetos sometidos a normas de Derecho administrativo en cada ámbito de regulación, así como teniendo en cuenta de las funciones sistemáticas que tales modelos están llamados a desempeñar. Tales funciones, que se abordarán de inmediato (infra, 4.3) ponen de manifiesto, a su vez, que los modelos que se formulen en este segundo escalón de la parte general presuponen la previa identificación de los ámbitos en que tal aproximación subjetiva es útil, por aportar soluciones dogmáticas y regulatorias que la perspectiva objetiva no se encuentra, al menos por el momento, en condiciones de proporcionar. Para la identificación de tales ámbitos se remite al lector a un apartado posterior (infra, 4.4.2).

\subsection{Funciones}

La renovación de la teoría de la relación juridico-administrativa en la parte general de la disciplina ha de acometerse a la luz de las funciones que está llamada a desempeñar desde dicha parte del sistema. En este sentido ha de tenerse en cuenta que la teoría de la relación jurídico-administrativa puede contribuir al desempeño las distintas funciones científicas atribuidas al Derecho administrativo general. Como es conocido, la ciencia contemporánea de la disciplina cifra en cuatro las funciones de la teorización sistemática de su parte general, a saber, una función dogmática, una función práctica o "de almacén", una función orientadora de la política legislativa y judicial, y una función de recepción del Derecho europeo ${ }^{143}$. Además, a continuación se procurará justificar que una aproximación subjetiva al Derecho administrativo que se apoye sobre una sólida teoría de la relación jurídica puede desempeñar importantes funciones heurísticas y comunicativas, además de poder operar, a resultas de todo ello, como un valioso instrumento para la complementación y actualización de la dogmática objetiva.

\footnotetext{
143 SCHMIDT-ASSMANN, 2003: 3 ss.
} 


\subsubsection{Dogmática}

La función dogmática de la parte general implica ordenar las especialidades recogidas en el Derecho administrativo sectorial y poner de relieve su conexión con las exigencias jurídicas generales -principalmente de rango constitucional- relevantes en cada caso. Este proceso facilita y orienta la creación, interpretación y aplicación del Derecho administrativo sectorial, pero al mismo tiempo propicia la constante revisión de la parte general a la luz de las evoluciones y desarrollos presentes en las distintas normativas sectoriales. Con frecuencia, la función dogmática de las figuras del sistema se asocia a la capacidad de extracción inmediata de consecuencias normativas a partir de ellas.

Sin embargo, y como se ha señalado ya, la complejidad y diversidad de las relaciones jurídico-administrativas exige que su corpus teórico común o general esté dotado de un grado muy elevado de abstracción, lo que sin duda le resta capacidad dogmática en este nivel del sistema. No obstante, este escalón inicial de la construcción teórica resulta indispensable para ofrecer un marco común al desarrollo de los distintos tipos de relaciones jurídico-administrativas en un nivel de abstracción intermedio, en el que están llamadas a desplegar un mayor potencial dogmático. La función dogmática no se asocia tanto, pues, a la teoría de la relación jurídico-administrativa en general, como a las teorías de la relación subvencional, de servicio público, funcionarial, tributaria, sancionadora, expropiatoria, etcétera ${ }^{144}$.

\subsubsection{Práctica o de almacén}

La función práctica o de almacén consiste en proporcionar a los operadores jurídicos materiales que les ayuden a resolver casos difíciles (por ejemplo, mediante la integración de lagunas o el uso de analogías). Por lo tanto, esta función contribuye a facilitar la labor aplicativa del Derecho que corresponde a los órganos administrativos y judiciales ${ }^{145}$. La renovación de la teoría de la relación jurídico-administrativa en la parte general del sistema -y, sobre todo, en su segundo escalón, o nivel intermedio- puede resultar particularmente útil desde esta perspectiva.

Hasta la fecha, y en ausencia de una teoría robusta al respecto en la parte general del sistema, el operador jurídico enfrentado a lagunas o ambigüedades en el Derecho administrativo positivo regulador de relaciones juridicas se ve abocado a navegar entre ingentes cantidades de material normativo, jurisprudencial y teórico, tanto de Derecho administrativo como, en caso de omisión o insuficiencia, de Derecho privado y de teoría del Derecho, para dotar de significado y efectos al Derecho aplicable. Por supuesto, esta consecuencia no se produce con la misma intensidad en todos los casos. Existe un corpus teórico bastante desarrollado, por ejemplo -aunque parcialmente

144 SCHMIDT-ASSMANN, 2003: 315-317.

145 SCHMIDT-ASSMANN, 2003: 3 ss. 
falto de actualización y de sistematización crítica- por lo que respecta a las nociones de potestad administrativa y de derecho subjetivo. No ocurre lo mismo, sin embargo, con las nociones de carga, precario administrativo, condición, modo, relación multipolar, etc. El mero intento de recopilar y reordenar, de manera sistemática y bajo sus actuales parámetros de Derecho constitucional y europeo, los materiales existentes sobre estas figuras, resulta valioso para ulteriores desarrollos en normativa, doctrina y jurisprudencia, por la función "almacén" o repositorio que corresponde a la parte general y a su teorización. Además, la incorporación actualizada de estos elementos estructurales a la parte general disminuye el riesgo de interpretaciones sesgadas, por falta de contexto, del operador jurídico que en la actualidad se ve obligado a indagar en materiales no adaptados a las vigentes coordenadas de Derecho general ni sectorial.

\subsubsection{Orientadora}

Lo que acaba de indicarse resulta extensible también a la función de orientación de la politica legislativa y judicial. Desde esta perspectiva, el Derecho administrativo general permite discernir las contradicciones y las soluciones defectuosas presentes en la regulación sectorial, racionalizar su desarrollo y contener su tendencia a la dispersión. Sin embargo, nuevamente aquí, y probablemente de modo más intenso que en el caso de la función práctica o de almacén, la teoría de la relación jurídicoadministrativa puede resultar más útil en un segundo escalón de abstracción, a medio camino entre la parte general y los sectores de la parte especial.

\subsubsection{Integradora}

La teoría de la relación jurídico-administrativa, así como la perspectiva subjetiva apoyada en ella, adquieren también importancia desde el punto de vista de la función de recepción del Derecho Europeo. En la medida en que este se ocupa prioritariamente no de disciplinar el estatuto y la actividad de la Administración, sino de ordenar relaciones jurídicas complejas - prioritariamente, aunque no solo, relaciones de mercado-, la aproximación en clave subjetiva juega un papel esencial para superar las deficiencias de una doctrina de las formas y tipos de actividad administrativa que ha sido ya desbordada por la normativa y jurisprudencia europeas. Además, y como se señaló antes, la importancia atribuida por el Derecho de la Unión a los derechos individuales y a sus obligaciones correlativas mediante la técnica de la subjetivación funcional está impulsando la revisión de la teoría de las posiciones jurídico-subjetivas de ciudadano y Administración, además de abrir al operador jurídico nacional nuevas perspectivas regulatorias en las que los intereses e incentivos de cada uno de los sujetos implicados pasan a ocupar un lugar estratégico. 


\title{
4.3.6. Heuristica y comunicativa
}

Además de las anteriores, a la figura de la relación jurídica le corresponden también importantes funciones heurísticas y comunicativas en el marco del tratamiento científico del Derecho administrativo. Debido a su enfoque sustantivo, a su apertura a la multipolaridad, y a su flexibilidad temporal, la idea de relación jurídica constituye un ángulo de observación de la realidad que permite tener en cuenta todos los elementos jurídicamente relevantes en un contexto determinado, así como las conexiones recíprocas entre ellos, y facilita la identificación de las situaciones de peligro o las necesidades de protección ${ }^{146}$. Asimismo, hacer explícita la lógica subjetiva de las figuras e instituciones jurídico-administrativas que normalmente se construyen y analizan, exclusiva o prioritariamente, desde una perspectiva objetiva o formal, permite descubrir conexiones de sentido entre fenómenos jurídicos aparentemente desconectados o, cuanto menos, no estrechamente relacionados entre sí. Utilizar la perspectiva subjetiva como clave de lectura permite, así, mejorar la comunicación entre distintos ámbitos del Derecho positivo y sus correspondientes elaboraciones teóricas, y abre con ello nuevas vías a la formación de conocimiento. Estas conexiones pueden producirse entre distintas figuras del Derecho administrativo; entre figuras pertenecientes a distintas ramas del Derecho; o entre construcciones propias de distintos ordenamientos jurídicos.

\begin{abstract}
Esta mejora comunicativa, y la apertura de nuevas perspectivas de análisis, se produce, por ejemplo, cuando el control judicial y la responsabilidad patrimonial de la Administración son analizados en clave subjetiva, como distintos mecanismos de tutela (primaria y secundaria) de las posiciones activas de los afectados por la actuación administrativa ${ }^{147}$. Algo similar sucede cuando los problemas foráneos del contencioso objetivo francés, el interesse legittimo italiano y la Schutznormtheorie alemana se analizan desde la óptica de la teoría de las situaciones jurídicosubjetivas ${ }^{148}$. Y, en fin, también se fomenta una nueva clave de lectura de la realidad, que facilita la comunicación entre Derecho público y privado, cuando se utiliza la idea de relación jurídica para sistematizar las exposiciones de Derecho administrativo ${ }^{149}$.
\end{abstract}

\subsubsection{Complementaria y renovadora}

Finalmente, y como se deduce de lo expuesto en los epígrafes anteriores (supra 3), corresponde a la teoría de la relación jurídico-administrativa una irrenunciable función de complemento y actualización de la dogmática objetiva. Las carencias, antes reseñadas, de la construcción objetiva actual no suponen, desde luego, que deba abandonarse esta perspectiva, ni que la construcción de la disciplina deba adoptar

146 SCHMIDT-ASSMANN, 1993: 26 ss., y 2003: 313-314, 337.

147 Un ejemplo de esta aproximación en DÍEZ SASTRE, 2012 y 2015.

148 MEDINA ALCOZ, 2016.

149 Marcello CAETANO, Tratado elemental de Derecho administrativo (teoría general), Librería y editorial Sucesores de "Galî", Santiago de Compostela, 1946; véase en particular el prólogo de Laureano LÓPEZ RODÓ (p. 10). 
un lenguaje únicamente subjetivo. De hecho, probablemente esté justificado seguir otorgando prioridad a un Derecho administrativo explicado desde la óptica de la actividad administrativa y de su control, ya que es del lado de la Administración de donde surgen la mayoría de especialidades de las relaciones jurídico-públicas. Lo que pretende ponerse de manifiesto es que ambos enfoques pueden y deben ser utilizados de manera complementaria ${ }^{150}$. La teoría de la relación jurídico-administrativa abre, así, un segundo acceso a la formación como sistema del Derecho administrativo ${ }^{151}$.

De la correcta aprehensión de la relación juridica subyacente dependen, entre otros extremos, las decisiones relativas al diseño de los procedimientos, las formas de actuación, el tipo de actividad administrativa, las formas más adecuadas de enforcement, los mecanismos óptimos de tutela, etc. Por ello, la renovación de la teoría de la relación jurídico-administrativa, la identificación de sus problemas regulatorios típicos, y el desarrollo de una tipología de sus concreciones más características, puede constituir un instrumento valioso para diseñar, interpretar, aplicar y explicar el Derecho administrativo de manera más adecuada a sus presupuestos europeos, constitucionales y sectoriales ${ }^{152}$.

Un ejemplo extraído del régimen europeo de las ayudas de Estado puede servir para ejemplificar cuanto acaba de decirse. Aquí, la toma en consideración de los intereses e incentivos de quien ha obtenido una ayuda de Estado, así como de sus competidores, está sirviendo a la Comisión Europea para diseñar estrategias de regulación y de ejecución a través del uso de mecanismos que pasarían desapercibidos desde una perspectiva tradicional, enfocada únicamente al control, por parte de la Unión, de las obligaciones objetivas establecidas sobre un Estado miembro. Desde el punto de vista de la regulación, la presión externa que pueden ejercer no solo los Estados miembros destinatarios de la normativa sobre ayudas de Estado, sino también los adjudicatarios de tales ayudas y sus competidores, es un elemento a tener en cuenta a la hora de decidir acerca del margen adecuado de discrecionalidad de la potestad de control de la Comisión (fenómeno de la llamada «autonomy by the rules») ${ }^{153}$. En el plano de la ejecución o enforcement ante los jueces nacionales, recientemente se ha mostrado cómo el tipo de obligación impuesta a los Estados miembros por el Derecho de las ayudas de Estado (de no hacer, de hacer, etc.) es relevante para diseñar los procedimientos de control y para asignar distintos roles en ellos a los competidores. Asimismo se ha expuesto que, para que la entrada en juego del individuo (o empresa) contribuya de manera eficaz a mejorar el control del efectivo cumplimiento de la normativa europea, es ne-

150 BAUER, 1993: 148, con ulteriores referencias; SCHMIDT-ASSMANN, 2003: cap. 1, marg. 27-29.

151 RUPP, 1965: 15 ss.; Gröschner, 1992: 67 ss.; SCHMIDT-ASSMANN, 2003: cap. 6, marg. 39).

152 Así, señaladamente, en el caso de las relaciones jurídico-administrativas multipolares: GRÖSCHNER, 1992; SCHMIDT-PREUSS, 1992; Ferdinand WOLLENSCHLÄGER, Verteilungsverfahren. Die staatliche Verteilung knapper Güter: Verfassungs- und unionsrechtlicher Rahmen, Verfahren im Fachrecht, bereichsspezifische verwaltungsrechtliche Typen-und Systembildung, Mohr Siebeck, Tübingen, 2010; DÍEZ SASTRE, 2012; UTRILLA FERNÁNDEZ-BERMEJO, 2015; ARROYO JIMÉNEZ y UTRILLA FERNÁNDEZ-BERMEJO, 2015; PAREJO ALFONSO, 2016; PASTOR-MERCHANTE, 2017; Luis ARROYO JIMÉNEZ y Dolores UTRILLA FERNÁNDEZ-BERMEJO (dirs.), La adjudicación administrativa de recursos escasos. Ordenación sectorial y reconstrucción sistemática, Tirant lo Blanch, Valencia, 2018; BAÑO LEÓN, 2018.

153 PASTOR-MERCHANTE, 2017: 1-2, con ulteriores referencias. 
cesario que aquel disponga no solo de adecuados canales de acceso (activación de los mecanismos de control), sino también de incentivos suficientes para actuar como «fiscal privado» (capacidad de influencia en el proceso decisorio -a través de derechos procesales de audiencia- y posibilidades reales de obtener beneficios - por ejemplo, mediante una disminución de la carga probatoria en la reclamación de damages-) ${ }^{154}$.

\subsection{Materiales}

\subsubsection{De alcance general}

El desarrollo y renovación de la teoría de la relación jurídico-administrativa en la parte general del sistema, tanto en su nivel superior de abstracción como en su nivel intermedio, exige realizar un esfuerzo de ordenación e integración sistemática de elementos normativos, jurisprudenciales y doctrinales provenientes de diversos ámbitos, y que pueden sistematizarse según su presencia en el Derecho general o sectorial.

En el plano general, de manera prioritaria han de tenerse en consideración los mandatos de rango constitucional (tanto españoles como europeos) que enmarcan en la actualidad la posición subjetiva correlativa de poder público y ciudadano. Esas normas de rango superior contienen decisiones valorativas fundamentales que deben impregnar el entero ordenamiento jurídico, y por lo tanto la reconstrucción de la teoría de la relación jurídico-administrativa debe partir de la deducción a partir de ellas. Particular consideración merecerá aquí, como es natural, y aunque no sea el objeto exclusivo ni prioritario de este estudio, la teoría de los derechos fundamentales, así como la cláusula de Estado democrático y la consiguiente corresponsabilidad de poder público e individuos en la satisfacción de los intereses generales (cfr. supra, xxx).

Asimismo, deben asimilarse los materiales ya existentes en la parte general del Derecho administrativo, que en la materia aquí estudiada son particularmente los referidos al procedimiento administrativo, al control jurisdiccional, a la doctrina de las formas de actuación (sobre todo, la regulación y la dogmática del acto administrativo) y a la sistematización de las clases de actividad.

Adicionalmente, y con carácter transversal, puede resultar también de utilidad acudir a la teoría general de la relación jurídica largamente construida y revisada por la teoría del Derecho y por la doctrina iusprivatista. A pesar de la superación del Derecho civil como Derecho común ${ }^{155}$, y de las diferencias entre las relaciones jurídicas de Derecho administrativo y las netamente privadas, no cabe renunciar sin más a este repositorio científico y dogmático, que puede arrojar luz, de manera instrumental, en la construcción de una teoría general de la relación jurídico-administrativa.

154 PASTOR-MERCHANTE, 2017: 37-40, 75-76.

155 Francisco VELASCO CABALLERO, "Introducción al Derecho administrativo", 2020, en prensa. 


\subsubsection{De alcance sectorial}

Como acaba de indicarse, la renovación de la doctrina de la relación jurídicoadministrativa en la parte general del sistema debe nutrirse de elementos constitucionales y europeos (así como de otros provenientes de la parte general del Derecho administrativo, del Derecho civil e incluso del ámbito de la teoría del Derecho), pero también de otros especiales o sectoriales. Desde este segundo punto de vista, resulta crucial seleccionar ámbitos sectoriales adecuados para la construcción cientifica, teniendo en cuenta que esa adecuación depende, entre otros factores, de la relevancia del sector dentro de la disciplina y de su capacidad de innovación ${ }^{156}$.

El desarrollo teórico de la relación jurídico-administrativa, sobre todo por lo que se refiere a su nivel de abstracción intermedio, debe atender, por una parte, a aquellas áreas clásicas del Derecho administrativo construidas sobre relaciones jurídicas típicas (por ejemplo, la relación sancionadora, la relación subvencional, la relación expropiatoria, o la relación de servicio público). Pero, de otro lado, resulta necesario atender también a aquellas otras áreas del Derecho administrativo que más se alejan del paradigma tradicional sobre cuya base se configuró la teoría de las formas y de los tipos de Administración. Es aquí, precisamente, donde con mayor vigor se manifiesta el potencial de la figura de la relación jurídico-administrativa como herramienta de ordenación teórica.

A continuación se propone una aproximación tópica y abierta -y, por tanto, sin pretensiones sistemáticas ni exhaustivas - a algunas de estas "nuevas" áreas del Derecho administrativo que pueden servir como campos de referencia para la renovación de la teoría general de la relación jurídico-administrativa. Las expresiones «ámbitos», «áreas», o "campos» de referencia se utilizan aquí de modo deliberadamente ambiguo, precisamente para eludir la discusión relativa a si los ejemplos que a continuación se mencionarán constituyen o no «sectores» de referencia en el sentido con que este concepto suele utilizarse en la ciencia del Derecho administrativo. De hecho, las áreas propuestas a continuación constituyen, más que sectores, agrupaciones o clases de estos y, por tanto, pertenecen más bien al segundo escalón de abstracción de la parte general. Son idóneos, por lo tanto, para el desarrollo de «modelos» intermedios de relaciones jurídico-administrativas (cfr. supra, 4.2.2).

Los tópicos que a continuación se proponen comparten como rasgo común su difícil racionalización jurídica a través de una contemplación meramente objetiva de la actuación administrativa. Las razones pueden ser principalmente dos, y darse de manera independiente o simultánea. Por una parte, puede tratarse de ámbitos en los que las constelaciones subyacentes de intereses son más complejas que la mera relación tradicional (defensiva) Estado-ciudadano, esto es, casos de relaciones jurídicas multipolares. En ellas es frecuente, además, que la Administración asuma un rol de garante sobre las actuaciones realizadas por algunos sujetos privados respecto de otros. De

156 Eberhard SCHMIDT-ASSMANN, Verwaltungsrechtliche Dogmatik. Eine Zwischenbilanz zu Entwicklung, Reform und künftigen Aufgaben, Mohr Siebeck, Tübingen, 2013, p. 9. 
otra parte, puede tratarse de supuestos en que la actividad administrativa formal no existe o ha reducido su presencia, de manera que la relación jurídica material subyacente pasa a un primer plano. En definitiva, se parte aquí de la premisa de que en estos ámbitos la teoría de la relación jurídico-administrativa puede desempeñar un rol crucial, no solo en cuanto a la interpretación y aplicación de los correspondientes programas normativos y su ordenación dogmática, sino también por lo que respecta a su configuración positiva mediante leyes, disposiciones generales, planes y programas. A algunos de estos campos se ha hecho ya alusión durante las páginas anteriores de este estudio. Veamos.

\subsubsection{La actividad prestacional del Estado social}

La relación jurídico-administrativa lleva ya tiempo manifestándose como una figura esencial para la ordenación positiva y teórica de la actividad administrativa de reconocimiento y suministro de prestaciones materiales diseńadas a la medida de su destinatario (pacientes en centros hospitalarios, drogodependientes, personas en situación de dependencia, etc.). Debido al disminuido rol de la actividad administrativa formal, al carácter personal de la prestación y a la consiguiente pérdida de capacidad directiva del Derecho objetivo, resulta aqui necesario partir de la relación juridica entre entidad prestadora y beneficiario (por ejemplo, entre médico y paciente) con vistas al diseño de garantias de procedimiento y organización que permitan a la Administración concretar el contenido de la correspondiente prestación con niveles adecuados de participación del ciudadano, de manera que la actuación administrativa cumpla eficazmente su función sin merma de los derechos individuales ${ }^{157}$.

Además, la figura de la relación jurídica (multipolar) deviene un ángulo de observación imprescindible cuando se trata de prestaciones llevadas a cabo por entidades colaboradoras $y$, por tanto, la constelación de intereses en juego pasa a ser multipolar ${ }^{158}$. Piénsese a estos efectos, por ejemplo, en el Sistema para la Autonomía y Atención a la Dependencia, configurado normativamente como «una red de utilización pública que integra, de forma coordinada, centros y servicios, públicos y privados», para cuyo funcionamiento «los poderes públicos promoverán la colaboración solidaria de los ciudadanos con las personas en situación de dependencia, a través de la participación de las organizaciones de voluntarios y de las entidades del tercer sector» (arts. 6.2 y 16.4 de la Ley 39/2006, de 14 de diciembre).

\subsubsection{La autorregulación regulada}

La relación jurídico-administrativa también pasa a un primer plano en el contexto de la autorregulación regulada. Se utilizará aquí como ejemplo una de las prin-

157 RODRÍGUEZ DE SANTIAGO, 2007: 87 ss.

158 SCHMIDT-ASSMANN, 2003: 150-151. 
cipales manifestaciones de esta, en su acepción de mecanismo de autocontrol ${ }^{159}$ : la sustitución, en ciertos ámbitos del Derecho público económico, de la figura de la autorización administrativa previa por declaraciones previas y/o por comunicaciones responsables. Como se señaló más atrás, este es uno de los ámbitos donde con mayor crudeza se manifiestan los problemas derivados de la tradicional dependencia dogmática del Derecho administrativo respecto de las figuras formales del procedimiento y del acto. En efecto, este fenómeno de autocontrol implica la desaparición del procedimiento administrativo ex ante, que por tanto deja de cumplir su función de ponderación entre interés general e intereses particulares, así como de facilitar la participación ciudadana en la toma de decisiones vinculantes ${ }^{160}$. La eliminación de la actuación administrativa formal de control preventivo, y su sustitución por una función de supervisión y control represivo, colocan en una situación de indefensión (o de defensa meramente ex post) a los titulares de derechos e intereses negativamente afectados por el inicio y desarrollo de la actividad de que se trate, pues con el procedimiento previo desaparece también su derecho de audiencia ${ }^{161}$; a la vez que se coloca al titular de la actividad en una permanente posición de precariedad ${ }^{162}$.

La eliminación de la actuación administrativa previa, de ordinario necesaria para concretar la relación jurídica entre los sujetos afectados por la actividad en cuestión, afecta también al reparto de funciones entre legislador y Administración. A falta de intermediación administrativa concretizadora, ha de ser la norma juridica la que defina de manera precisa las situaciones juridicas correlativas de cada una de las partes. Desde esta perspectiva, la teoría de la relación jurídico-administrativa puede resultar especialmente útil para orientar la labor del legislador (o de la Administración que desarrolla reglamentariamente sus mandatos). En efecto, en estos casos «la norma adquiere un carácter habilitador desconocido hasta el momento, lo que hace imprescindible una mejor y más clara regulación de los requisitos a cumplir por parte de los titulares de las actividades [...] y de las mismas actividades, con un claro reparto de responsabilidades, en su caso, ante los eventuales incumplimientos, así como las sanciones administrativas que procedan, los derechos de terceros y sus garantías» ${ }^{163}$.

159 Mercé DARNACULLETA i GARDELLA, Autorregulación y Derecho público: la autorregulación regulada, Marcial Pons, Madrid-Barcelona, 2005, pp. 296-297.

160 Dolors CANALS i AMETLLER, "La aplicación del Derecho público a relaciones entre particulares", Comunicación presentada en el I Seminario de Teoría y Método, Universidad de Valencia, 2013, disponible en www.academia.edu.

161 CANALS i AMETLLER, ibid.; BAÑO LEÓN, 2018. En relación con los supuestos en que las facultades de control ex post de la Administración se encuentran sometidas a plazo, M. ${ }^{a}$ Carmen NÚNÉZ LOZANO, Las actividades comunicadas a la Administración. La potestad administrativa de veto sujeta a plazo, Marcial Pons, Madrid, 2001, pp. 179-187.

162 Juan Alfonso SANTAMARÍA PASTOR, "Los proyectos de Ley del Procedimiento Administrativo Común de las Administraciones Públicas y de Régimen Jurídico del Sector Público. Una primera evaluación”, Documentación Administrativa, núm. 2, 2015, 15 pp. (p. 11); BAÑO LEÓN, 2018: 3.

163 CANALS i AMETLLER, 2013. 


\subsubsection{La actividad de regulación y supervisión económica}

El desplazamiento al sector privado de la titularidad de ciertas actividades económicas de interés general para su prestación en régimen de libre competencia ha dado lugar la proliferación de relaciones juridicas entre particulares (operadores y usuarios del servicio), en las que, por la persistencia de un interés público sustantivo, interviene también la Administración realizando funciones reguladoras, inspectoras y supervisoras, y a las que se aplica en mayor o menor medida el Derecho administrativo. En estos casos, la autoridad administrativa utiliza instrumentos formales heterogéneos (principalmente, reglamentos y actos) cuya elaboración teórica es a veces insuficiente para ordenar este tipo de actividad administrativa y, en concreto, para racionalizar el régimen jurídico de los operadores que prestan el servicio. Por ello, la figura de la relación jurídica puede encontrar aquí uno de sus campos de aplicación más fecundos ${ }^{164}$. En particular, los especiales rasgos de la relación existente entre usuarios y operadores ha sido uno de los argumentos utilizados para propugnar la extensión a estos últimos de ciertas obligaciones y exigencias históricamente construidas para su aplicación a la Administración, y explica el reconocimiento frente a ellos de garantías específicas de los usuarios ${ }^{165}$.

\subsubsection{La adjudicación administrativa de recursos escasos}

La elaboración teórica de la actividad de adjudicación de derechos limitados en número como segmento de la parte general de la disciplina con un grado de abstracción intermedio se fundamenta en la hipótesis de que este tipo de actividad plantea problemas característicos, derivados a su vez de la existencia de una relación jurídica de concurrencia entre varios particulares a ser resuelta por la Administración. De ello se sigue que la construcción sistemática de este tipo de actividad debe partir de la identificación de las posiciones jurídico-privadas y de los intereses públicos en juego en cada una de sus manifestaciones sectoriales, así como de la consideración de su interdependencia, de modo que sea posible diseñar patrones o modelos normativos típicos coherentes con las exigencias constitucionales (europeas a internas) afectadas en cada supuesto, así como con las necesidades y condicionamientos propios de cada tipo de materia o sector sobre el que la actividad de adjudicación se proyecta ${ }^{166}$.

Así, la relación multipolar de concurrencia resulta un elemento de esencial consideración para el diseño del programa de adjudicación, el procedimiento administrativo para su aplicación, la estabilidad de la decisión de adjudicación ${ }^{167}$, y las formas y vías de tutela de los licitadores ${ }^{168}$. Por ejemplo, los peculiares rasgos de la relación

164 PAREJO ALFONSO, 2016, con amplias referencias.

165 Mariola RODRÍGUEZ FONT, "Protección y garantía de los usuarios desde las técnicas e instituciones de la regulación”, en Santiago MUÑOZ MACHADO (dir.), Derecho de la regulación económica. Tomo I. Fundamentos e instituciones de la regulación, Iustel, Madrid, 2010, pp. 829-880.

166 UTRILLA FERNÁNDEZ-BERMEJO, 2018.

167 WOLLENSCHLÄGER, 2010; WOLLENSCHLÄGER, 2015; ARROYO JIMÉNEZ, 2015.

168 DÍEZ SASTRE, 2012; DÍEZ SASTRE, 2015. 
jurídica subyacente pueden traducirse en una importancia reforzada de la igualdad procedimental, así como de los deberes administrativos de objetividad y neutralidad; exigir una intensificación de las consecuencias de los vicios de procedimiento; justificar la introducción de mecanismos de control judicial ex ante, así como una mayor generosidad del régimen de tutela cautelar; abogar por una flexibilización en la prueba de la efectividad y la causalidad del dańo a efectos indemnizatorios; etc.

\subsubsection{Los daños legítimos}

En el Estado social y democrático de Derecho, las normas pueden habilitar a la Administración para sacrificar o lesionar los derechos subjetivos de ciertos sujetos con la finalidad de proteger determinados intereses públicos (o privados con relevancia social) considerados de importancia prevalente, siempre y cuando se respeten ciertos limites derivados de la Constitución (en particular, que la intervención sea proporcionada, que se indemnice el daño causado y, si lo afectado es un derecho fundamental, que exista previsión legislativa y se respete el contenido esencial del derecho desplazado o sacrificado) ${ }^{169}$. Así, sucede, por ejemplo, con los daños causados legítimamente por las fuerzas y cuerpos de seguridad en ejercicio de sus funciones; el sacrificio de animales para evitar la propagación de enfermedades contagiosas; los perjuicios derivados de la realización de obras públicas que limitan el acceso a locales comerciales; los dańos causados por la revocación de actos administrativos válidos; o, en fin, la expropiación forzosa, que es probablemente la manifestación más característica de esta categoría.

En los casos en que el beneficiario de la medida es un sujeto distinto de la propia Administración (o la colectividad a la que esta encarna), la producción de este tipo de daños da lugar a relaciones jurídicas multipolares entre Administración, víctima del daño y beneficiario de este. No obstante, el Derecho positivo no se hace aún eco de manera suficiente de esta situación. La legislación sobre expropiación forzosa es claro testimonio de ello. Con anterioridad se mencionó que esta normativa no tiene suficientemente en cuenta que la relación jurídica subyacente no finaliza cuando lo hace el procedimiento expropiatorio, sino que se prolonga más allá de ese momento. Cabe añadir ahora que esas normas, a pesar de contemplar la posibilidad de que exista un beneficiario disociado del ente expropiante, diseñan la actividad expropiatoria en clave bipolar y estrictamente formal. A ello se suma, en fin, la parquedad con que esos elementos formales (procedimiento y acto expropiatorio) se encuentran contemplados en la normativa vigente.

La definición de las posiciones jurídicas correlativas de Administración sacrificante, sujeto perjudicado y beneficiario deviene imprescindible como instrumento para colmar lagunas regulatorias planteadas por la conjunción de todos estos factores, asi como para

169 Sobre la figura de los daños autorizados o legítimos, véase Luis MEDINA ALCOZ, "El problema de la culpa en el Derecho de daños", en Raúl LETELIER WARTENBERG (coord.), La falta de servicio, Abeledo Perrot-Thomson Reuters, Santiago de Chile, 2012, pp. 363 ss., y UTRILLA FERNÁNDEZ-BERMEJO, 2015: 39-44, con ulteriores referencias. 
realizar propuestas de reforma normativa de la institución. Por ejemplo, el silencio de la Ley de Expropiación Forzosa acerca de las consecuencias del impago del justiprecio, más allá del devengo de intereses de demora y la retasación, obliga a acudir a la parte general en busca de los conceptos de obligación, deber y/o carga, para determinar si es posible o no, en caso de impago, proceder a la ejecución forzosa, a la revocación de la decisión administrativa, y/o a la imposición de sanciones. Otro tanto ocurre con el gravamen de destinar lo expropiado a la causa expropiandi, o a la responsabilidad subsidiaria de la Administración expropiante en caso de insolvencia del beneficiario privado sobrevenida antes de haberse abonado completamente el montante debido en concepto de justiprecio ${ }^{170}$.

\section{BIBLIOGRAFÍA}

Norbert ACHTERBERG, Die Rechtsordnung als Rechtsverhältnisordnung: Grundlegung der Rechtsverbältnistheorie, Duncker \& Humblot, Berlín, 1982.

—, Allgemeines Verwaltungsrecht. Ein Lehrbuch, 2a ed., C.F. Müller, Heidelberg, 1986.

Albertina ALBORS-LLORENS, Private Parties in EC Law, Oxford University Press, Oxford, 2006.

Renato ALESSI, Sistema istituzionale del Diritto amministrativo italiano, 2a ed., Giuffrè, Milán, 1958.

Juan-Cruz ALLI ARANGUREN, La construcción del concepto de Derecho administrativo español, Thomson Civitas, Cizur Menor, 2006.

Sabino ÁLVAREZ-GENDÍN, Tratado General de Derecho Administrativo. Tomo I, Bosch, Barcelona, 1958.

Luis ARROYO JIMÉNEZ, "La adjudicación administrativa de recursos escasos", InDret, Revista para el Análisis del Derecho, 1/2015, 2015.

Luis ARROYO JIMÉNEZ y Dolores UTRILLA FERNÁNDEZ-BERMEJO (dirs.), La adjudicación administrativa de recursos escasos. Ordenación sectorial y reconstrucción sistemática, Tirant lo Blanch, Valencia, 2017.

Jean-Bernard AUBY, (2017), "The Transformation of the Administrative State and Administrative Law", en Armin VON BOGDANDY, Peter M. HUBER y Sabino CASSESE (eds.), The Administrative State. Volume 1, Oxford University Press, Oxford, 2017, pp. 601-630.

Loïc AZOULAI, Ségolène BARBOU DES PLACES y Etienne PATAUT (eds.), Constructing the Person in EU Law: Rights, Roles, Identities, Hart Publishing, Oxford, 2016.

Otto BACHOF, "Die Dogmatik des Verwaltungsrechts vor den Gegenwartsaufgaben der Verwaltung", VVDStRL, núm. 30, 1972, pp. 193-244.

José María BAÑO LEÓN, "Derecho al procedimiento en la relación administrativa multipolar (los derechos fundamentales como límite a la renuncia del legislador al control previo de actuaciones)", Revista Española de Derecho Administrativo, núm. 189, 2018, pp. 47-64.

Javier BARNÉS VÁZQUEZ, "Introducción. Reforma e innovación del procedimiento administrativo", en Javier BARNÉS VÁZQUEZ (ed.), La transformación del procedimiento administrativo, Global Law Press, Sevilla, 2008, pp. 15-69.

—, "La transposición de valores públicos a los agentes privados por medio de elementos de organización y de procedimiento", en Maria Mercé Darnaculleta, José Esteve PARDO e Indra SPIECKER (eds.), Estrategias del Derecho ante la incertidumbre y la globalización, Marcial Pons, Madrid, 2015, pp. 281-311.

Hartmut BAUER, “¿Transformación radical en la doctrina del Derecho administrativo? Las formas y las relaciones jurídicas como elementos de una dogmática jurídico-administrativa actual”, Documentación Administrativa, núm. 234, 1993, pp. 133-160.

170 UTRILLA FERNÁNDEZ-BERMEJO, 2015: 220 ss., 269 ss. 
José BERMEJO VERA, Derecho administrativo básico. Parte General, 9a ed., Thomson / Civitas, Cizur Menor, 2009.

Albert BLECKMANN, Zur Dogmatik des Allgemeinen Verwaltungsrechts I. Die Handlungsmittel der Verwaltung in rechtsvergleichender Sicht, Nomos, Baden-Baden, 1999.

Marcello CAETANO, Tratado elemental de Derecho administrativo (teoría general). Librería y editorial Sucesores de "Gali", Santiago de Compostela, 1946 [trad. y notas de L. López Rodó].

Christian CALLIES, "Kohärenz und Konvergenz beim europäischen Individualrechtsschutz - Der Zugang zum Gericht im Lichte des Grundrechts auf effektiven Recthsschutz", Neue Juristische Wochenschrift, núm. 49, 2002, pp. 3577-3582.

Dolors CANALS i AMETLLER, "Principios, reglas y garantías propias del Derecho público en la prestación privada de servicios económicos de interés general", Revista Española de Derecho Administrativo, núm. 158, 2013, pp. 127-155.

—, "La aplicación del Derecho público a relaciones entre particulares", Comunicación presentada en el I STEM (Valencia), 2013, disponible en www.academia.edu

Francesco CARNELUTTI, Teoría general del Derecho. Comares, Granada, 2003 [trad. del original de 1940 por Carlos G. Posada].

Sebastiano CASSARINO, Le situazioni giuridiche e l'oggetto della giurisdizione amministrativa, Giuffrè, Milano, 1956.

Sabino CASSESE, Las bases del Derecho administrativo, INAP, Madrid, 1994 [original italiano de 1989, trad. de Luis Ortega].

Sabino CASSESE, Giulio NAPOLITANO y Lorenzo CASINI, "Towards multipolar administrative law: A theoretical perspective", I-CON, vol. 12, núm. 2, 2014, pp. 354-356.

René CHAPUS, Droit administratif general, 14a ed., Montchrestien, Paris, 2000.

Manuel CLAVERO ARÉVALO, Estudios de Derecho administrativo, Instituto García Oviedo - Civitas, Madrid, 1992

Manuel COLMEIRO, Derecho administrativo español. Tomo primero, Librerías de Don Ángel Calleja, Madrid - Santiago de Compostela, 1850.

—, Derecho administrativo español. Tomo primero, 4a ed., Imprenta y Librería de Eduardo Martínez, Madrid, 1876.

Luis COSCULLUELA MONTANER, Manual de Derecho administrativo, 28a ed., Thomson / Civitas, Cizur Menor, 2017.

Maria Mercé DARNACULLETA i GARDELLA, Autorregulación y Derecho público: la autorregulación regulada, Marcial Pons, Madrid-Barcelona, 2005.

Gráinne DE BÚRCA, "The language of rights and European integration”, en Jo SHAW y Gillian MORE (eds.), New Legal Dynamics of European Union, Oxford University Press, Oxford, 1996.

Bruno DE WITTE, "Direct Effect, Primacy, and the Nature of the Legal Order", en Paul CRAIG y Gráinne DE BÚRCA (eds.), The Evolution of EU Law, 2a ed., Oxford University Press, Oxford, 2011, pp. 323-362

Luis DÍEZ PICAZO, Fundamentos del Derecho civil patrimonial volumen I. Introducción. Teoría del contrato, $5^{a}$ ed., Civitas, Madrid, 1996.

Silvia DÍEZ SASTRE, La tutela de los licitadores en la adjudicación de contratos públicos, Marcial Pons, Madrid, 2012.

—, "La tutela de los competidores en los procedimientos administrativos de adjudicación", en Luis ARROYO JIMÉNEZ y Dolores UTRILLA FERNÁNDEZ-BERMEJO (dirs.), La administración de la escasez. Los fundamentos de la actividad administrativa de adjudicación de derechos limitados en número, Marcial Pons, Madrid, 2015, pp. 205-243.

—, La formación de conceptos en el derecho público. Un estudio de metodología académica: definición, funciones y criterios de formación de los conceptos jurídicos, Marcial Pons, Madrid, 2018.

Rafael ENTRENA CUESTA, Curso de Derecho admnistrativo. Volumen I/1. Concepto, fuentes, relación jurídico-administrativa y justicia administrativa, 12a ed., Tecnos, Madrid, 1998.

Antonio ESTEBAN DRAKE, El derecho público subjetivo como instrumentación técnica de las libertades públicas y el problema de la legitimación procesal, Civitas, Madrid, 1981. 
José ESTEVE PARDO, "La extensión del Derecho público. Una reacción necesaria”, Revista de Administración Pública, núm. 189, 2012, pp. 11-40.

—, La nueva relación entre Estado y sociedad. Aproximación al trasfondo de la crisis, Marcial Pons, Madrid, 2013.

—, Lecciones de Derecho administrativo, 6a ed., Marcial Pons, Madrid, 2016.

Recaredo FERNÁNDEZ DE VELASCO, La "acción popular" en el Derecho administrativo, Reus, Madrid, 1920.

-, El acto administrativo. Exposición doctrinal y estudio del Derecho español, Revista de Derecho Privado, Madrid, 1929.

Germán FERNÁNDEZ FARRERES, Sistema de Derecho administrativo, Thomson / Civitas, Cizur Menor, 2012.

Fritz FLEINER, Instituciones de Derecho Administrativo, Editorial Labor, Barcelona, 1933 [trad. de la $8^{\text {a }}$ edición alemana por S. Álvarez Gendín).

Ernst FORSTHOFF, Tratado de Derecho administrativo, Instituto de Estudios Políticos, Madrid, 1958 [5a ed. alemana, trad. Legaz Lacambra, Garrido Falla y Gómez de Ortega y Junge].

Ugo FORTI, Diritto amministrativo. Parte generale. Volume II. Il rapporto - La teoria degli atti, 4 a ed., Casa editrice Dott. Eugenio Jovene, Nápoles, 1947.

Jody FREEMAN, "The Private Role in Public Governance”, New York University Law Review, vol. 75, núm. 3, 2000, pp. 543-675.

Eduardo GAMERO CASADO y Severiano FERNÁNDEZ RAMOS, Manual básico de Derecho administrativo, 14a ed., Tecnos, Madrid, 2017.

Eduardo GARCÍA DE ENTERRÍA, Problemas del Derecho público al comienzo de siglo. Civitas, Madrid, 2001.

Eduardo GARCÍA DE ENTERRÍA y Tomás-Ramón FERNÁNDEZ, Curso de Derecho Administrativo II, $3^{\text {a }}$ ed., Civitas, Madrid, 1980.

-, Curso de Derecho Administrativo I, 17a ed., Aranzadi, Cizur Menor, 2015.

—, Curso de Derecho Administrativo II, 14ª ed., Aranzadi, Cizur Menor, 2015.

Carlos GARCÍA OVIEDO, Derecho Administrativo I, 8a ed., E.I.S.A., Madrid, 1962 [edición a cargo de E. Martínez Useros].

Jorge GARCÍA-ANDRADE GÓMEZ, Actuaciones administrativas sin procedimiento (relaciones jurídicas en el Estado de Derecho), en prensa.

José Antonio GARCÍA-TREVIJANO FOS, Curso de Derecho Administrativo. Tomo I, Vol. 1, Sección de Publicaciones del S. E. U. de Salamanca, Salamanca, 1961.

Fernando GARRIDO FALLA, Tratado de Derecho Administrativo. Volumen I (Parte General), 2a ed., Instituto de Estudios Políticos, Madrid, 1961.

Fernando GARRIDO FALLA, Alberto PALOMAR OLMEDA y Herminio LOSADA GONZÁLEZ, Tratado de Derecho Administrativo. Vol. I. Parte General, 14a ed., Tecnos, Madrid, 2003.

José GASCÓN Y MARÍN, Tratado elemental de Derecho administrativo. Principios y legislación española. Tomo primero. Doctrina general, 2a ed., Imprenta clásica española, Madrid, 1921.

—, Tratado de Derecho administrativo. Principios y legislación española. Tomo I, 5a ed., C. Bermejo Impresor, Madrid, 1933.

Massimo Severo GIANNINI, Diritto amministrativo. Volume secondo, $3^{\text {a }}$ ed., Giuffrè, Milán, 1933.

Rolf GRÖSCHNER, Das Überwachungsrechtsverhältnis: Wirtschaftsüberwachung in gewerbepolizeirechtlicher Tradition und wirtschaftsverwaltungsrechtlichem Wandel, Mohr, Tübingen, 1992.

Rolf GRÖSCHNER, "Vom Nutzen des Verwaltungsrechtsverhältnisses", Die Verwaltung, núm. 30, 1997, pp. 301-338.

Jaime GUASP DELGADO, "El derecho de carácter administrativo como fundamento del recurso contencioso", Revista de la Facultad de Derecho de Madrid, núm. 2, 1940, pp. 11-23 ss.

Peter HÄBERLE, Die Verfassung des Pluralismus, Athenaeum, Königstein, 1980.

—, "Die Menschenwürde als Grundlage der staatlichen Gemeinschaft", en Josef ISENSEE y Paul KIRCHHOF (eds.), Handbuch des Staatsrechts der Bundesrepublik Deutschland. Band I, C.F. Müller, Heidelberg, 1987, pp. 815-862 
—, Pluralismo y Constitución. Estudios de Teoría Constitucional de la sociedad abierta, Tecnos, Madrid, 2002 [traducción de E. Mikunda].

Maurice HAURIOU, "Préface", en su obra Précis de droit administratif et de droit public, 8 a ed., Sirey, Paris, 1914

—, Précis de droit administratif et de droit public, 11ª ed., Sirey, Paris, 1927.

Wilhelm HENKE, Das subjektive öffentliche Recht, Mohr, Tübingen, 1968.

—, "Die Rechtsformen der sozialen Sicherung und das Allgemeine Verwaltungsrecht", Veröffentlichungen der Vereinigung der Deutschen Staatsrechtslehrer, núm. 28, 1970, pp. 149-185.

Konrad HESSE, Derecho constitucional y Derecho privado, Civitas, Madrid, 1995.

Hermann HILL, Das fehlerhafte Verfahren und seine Folgen im Verwaltungsrecht, Decker, Heidelberg, 1986.

Herwig C. H. HOFMANN y Catherine WARIN, "Identifying individual rights in EU law", University of Luxembourg Law Working Paper, núm. 4, 2017, 23 pp.

Mathias HONG, "Subjektive Rechte und Schutznormtheorie im europäischen Verwaltungsraum", Juristen Zeitung, núm. 8, 2012, pp. 380-388.

Peter M. HUBER, Konkurrenzschutz im Verwaltungsrecht. Schutzanspruch und Rechtsschutz bei Lenkungsund Verteilungsentscheidungen der öffentlichen Verwaltung, Mohr, Tübingen, 1991.

Georg JELLINEK, System der subjektiven öffentlichen Rechte, Akademische Verlagsbuchhandlung von J.B.C. Mohr, Freiburg, 1892.

Walter JELLINEK, Verwaltungsrecht, Springer, Berlin, 1920.

-, Verwaltungsrecht, 2a ed., Springer, Berlin, 1929.

Matthias JESTAEDT, "Rechts als Relation. Skizzenhafte Anmerkungen zur Rechtsverhältnislehre", en Katharina GRÄFIN VON SCHLIEFFEN (ed.), Republik - Rechtsverhältnis - Rechtskultur. Mohr Siebeck, Tübingen, 2018, pp. 211-224.

Peter KRAUSE, Rechtsformen des Verwaltungshandelns. Überlegungen zu einem System der Handlungsformen der Verwaltung, mit Ausnahme der Rechtsetzung, Duncker \& Humblot, Berlin, 1974.

Thomas S. KUHN, La estructura de las revoluciones cientificas, 4a reimp., Fondo de Cultura Económica, México D. F., 2012 [trad. de Carlos Solís].

José Luis LACRUZ BERDEJO, Elementos de Derecho civil, Bosch, Barcelona, 1974.

Mitchel de S.-O.-l'E. LASSER, Judicial Transformations: The Rights Revolution in the Courts of Europe, Oxford University Press, Oxford, 2009.

Mariano LÓPEZ BENÍTEZ, Naturaleza y presupuestos constitucionales de las relaciones especiales de sujeción, Civitas / Universidad de Córdoba, Madrid, 1994.

Ramón MARTÍN MATEO y Juan José DÍEZ SÁNCHEZ, Manual de Derecho administrativo, 29a ed., Thomson Reuters, Cizur Menor, 2012.

Sebastián MARTÍN-RETORTILLO BAQUER, S. (1996), El Derecho civil en la génesis del Derecho administrativo y de sus instituciones, 2a ed., Civitas, Madrid, 1996.

Johannes MASING, Die Mobilisierung des Bürgers für die Durchsetzung des Rechts. Europäische Impulse für eine Revision der Lehre vom subjektiv-öffentlichen Recht, Duncker und Humblot, Berlin, 1997.

_, "Der Rechtsstatus des Einzelnen im Verwaltungsrecht", en Wolfgang HOFFMANN-RIEM, Eberhard SCHMIDT-ASSMANN y Andreas VOSSKUHLE (eds.), Grundlagen des Verwaltungsrechts. Band I. Methoden. Masstässe. Aufgaben. Organisation, 2a ed., C. H. Beck, Múnich, 2012, pp. $437-$ 542.

Hartmut MAURER, Derecho administrativo. Parte General, Madrid, Marcial Pons, 2011.

Otto MAYER, Deutsches Verwaltungsrechts. Band I, Duncker \& Humblot, Leipzig, 1895.

Luis MEDINA ALCOZ, Libertad y autoridad en el Derecho administrativo. Derecho subjetivo e interés legitimo: una revisión, Marcial Pons, Madrid, 2016.

—, "El problema de la culpa en el Derecho de daños", en Raúl LETELIER WARTENBERG (coord.), La falta de servicio, Abeledo Perrot-Thomson Reuters, Santiago de Chile, 2012, pp. 363 ss.

Fernando MELLADO, Tratado elemental de Derecho administrativo, 2a ed., Tipografía de los hijos de M. G. Hernández, Madrid, 1894.

Joana MENDES, Participation in EU Rulemaking. A Rights-Based Approach, Oxford University Press, Oxford, 2011. 
Joana MENDES, "Rule of law and participation: a normative analysis of internationalized rulemaking as composite procedures", International Journal of Constitutional Law, vol. 12, núm. 2, 2014, pp. 370-401.

Adolf MERKL, Teoría general del Derecho administrativo, Editorial Revista de Derecho Privado, Madrid, 1935 [edición al cuidado de J. L. Moreneo Pérez].

Wolfgang MEYER-HESEMANN, "Die paradigmatische Bedeutung Otto Mayers für die Entwicklung der deutschen Verewaltungsrechtswissenschaft", Rechtstheorie, núm. 13, 1982, pp. 496-502.

Oriol MIR PUIGPELAT, "The Book III of the ReNEUAL Model Rules from a Spanish Perspective: When Procedural Law Becomes Substantive", en Matthias RUFFERT (ed.), The Model Rules on EU Administrative Procedures: Adjudication. Europa Law Publishing, Amsterdam, 2016, pp. 70-83.

Luis MORELL OCAÑA, Curso de Derecho administrativo, $5^{\mathrm{a}}$ ed., Servicio de Publicaciones Facultad de Derecho de la Universidad Complutense de Madrid, Madrid, 2002.

Santiago MUÑOZ MACHADO, Tratado de Derecho Administrativo y Derecho Público General, 4 a ed., BOE, Madrid, 2015.

-, Tratado de Derecho Administrativo y Derecho Público General. Tomo I. Historia de las Instituciones Jurídico-administrativas-1, BOE, Madrid, 2015.

Ma Carmen NÚNEZ LOZANO, Las actividades comunicadas a la Administración. La potestad administrativa de veto sujeta a plazo, Marcial Pons, Madrid, 2001.

Vittorio Emmanuel ORLANDO, Principios de Derecho Administrativo, INAP, Madrid, 1978 [trad. de la $2^{\text {a }}$ ed. Italiana, de 1892 , por A. Rodríguez Bereijo)

Ramón PARADA VÁZQUEZ, Derecho administrativo (I, II, y III), 26a ed. (tomo I), 23a ed. (tomo II), $16^{\mathrm{a}}$ ed. (tomo III), UNED Ediciones Académicas, Madrid, 2017.

Luciano PAREJO ALFONSO, La vigilancia y la supervisión administrativas: un ensayo de su construcción como relación jurídica, Tirant lo Blanch, Valencia, 2016.

—, Lecciones de Derecho administrativo, 8a ed., Tirant lo Blanch, Valencia, 2016.

Fernando PASTOR-MERCHANTE, The Role of Competitors in the Enforcement of State Aid Law, Hart Publishing, London, 2017.

José Luis PÉREZ DE AYALA, Dinámica de la relación jurídica tributaria en el Derecho español, Dykinson, Madrid, 1997.

Miguel POIARES MADURO, We the Court: The European Court of Justice and the European Economic Constitution, Hart Publishing, Oxford, 1998

Adolfo POSADA HERRERA, Tratado de Derecho administrativo según las teorias filosóficas y la legislación positiva, Librería General de Victoriano Suárez, Madrid, 1898.

Miguel A. PRESNO LINERA, "La estructura de las normas de derechos fundamentales", en Francisco J. BASTIDA FREIJEDO et al, Teoria general de los derechos fundamentales en la Constitución Española de 1978, Tecnos, Madrid, 2004, pp. 45-56.

Richard RAWLINGS, "Engaged elites: Citizen Action and Institutional Attitudes in Commission Enforcement", European Law Journal, vol. 6, núm. 1, 2000, pp. 4-28.

Manuel REBOLLO PUIG y Diego J. VERA JURADO (dirs.), Derecho Administrativo. Tomo I. Conceptos fundamentales. Fuentes y Organización, $3^{\text {a }}$ ed., Tecnos, Madrid, 2017.

Enrique RIVERO YSERN, El Derecho administrativo y las relaciones entre particulares, ed. Instituto García Oviedo, Sevilla, 1969.

José María RODRÍGUEZ DE SANTIAGO, La administración del Estado Social. Marcial Pons, Madrid, 2009.

Mariola RODRÍGUEZ FONT, "Protección y garantía de los usuarios desde las técnicas e instituciones de la regulación”, en Santiago MUÑOZ MACHADO (dir.), Derecho de la regulación económica. Tomo I. Fundamentos e instituciones de la regulación, Iustel, Madrid, 2010, pp. 829-880.

Santi ROMANO, L'ordinamento giuridico, Sansoni, Firenze, 1951.

—, Frammenti di un Dizionario giuridico, Giuffrè, Milano, 1983.

Julie RONDU, L'individu, sujet du droit de l'Union européenne, Bruylant, París, 2020

Antonio ROYO-VILLANOVA, Elementos de Derecho Administrativo, 26a ed., Librería Santarén, Valladolid, 1964. 
Matthias RUFFERT, "Rights and Remedies in European Community Law: a Comparative View", Common Market Law Review, vol. 34, núm. 2, 1997, pp. 307-336.

Hans H. RUPP, Grundfragen der heutigen Verwaltungsrechtslehre. Verwaltungsrechtsnorm und Verwaltungsrechtsverhältnis, Mohr, Tübingen, 1965.

Miguel SÁNCHEZ MORÓN, La participación del ciudadano en la Administración pública, Centro de Estudios Constitucionales, Madrid, 1980.

—, Derecho administrativo. Parte general, 13a ed., Tecnos, Madrid, 2017.

Aldo M. SANDULLI, Manuale di diritto amministrativo, Casa editrice dott. Eugenio Jovene, Napoli, 1952.

Vicente SANTAMARÍA DE PAREDES, Curso de Derecho administrativo según sus principios generales y la legislación actual de España, $3^{a}$ ed., Establecimiento tipográfico de Ricardo Fé, Madrid, 1891.

-, Curso de Derecho politico según la filosofía politica moderna, la historia general de España y la legislación vigente, $6^{\mathrm{a}}$ ed., Establecimiento tipográfico de Ricardo Fé, Madrid, 1898.

—, Curso de Derecho administrativo según sus principios generales y la legislación actual de España, 8a ed., Imprenta Española, Madrid, 1914.

Juan Alfonso SANTAMARÍA PASTOR, "Los proyectos de Ley del Procedimiento Administrativo Común de las Administraciones Públicas y de Régimen Jurídico del Sector Público. Una primera evaluación", Documentación Administrativa, núm. 2, 2015, 15 pp.

—, Fundamentos de Derecho administrativo I. Centro de Estudios Ramón Areces, Madrid, 1988.

—, Principios de Derecho Administrativo General I, $3^{\text {a }}$ ed., Iustel, Madrid, 2015.

Eberhard SCHMIDT-ASSMANN, "Der Rechtsstaat", en J. Isensee \& P. Kirchhof (eds.), Handbuch des Staatsrechts der Bundesrepublik Deutschland. Band I, C.F. Müller, Heidelberg, 1987, pp. 987-1044.

—, "La doctrina de las formas jurídicas de la actividad administrativa. Su significado en el sistema del Derecho administrativo y para el pensamiento administrativo actual", Documentación Administrativa, núms. 235-236, 1993, pp. 7-31.

—, La teoría general del Derecho administrativo como sistema, Marcial Pons, Madrid, 2003.

-, Verwaltungsrechtliche Dogmatik. Eine Zwischenbilanz zu Entwicklung, Reform und künftigen Aufgaben, Mohr Siebeck, Tübingen, 2013.

Matthias SCHMIDT-PREUSS, Kollidierende Privatinteressen im Verwaltungsrecht. Das subjektive öffentliche Recht im multipolaren Verwaltungsrechtsverhältnis, Duncker \& Humblot, Berlin, 1992.

Fiedrich SCHOCH, Vorläufger Rechtsschutz und Risikoverteilung im Verwaltungsrecht, Decker, Heidelberg, 1988.

Martin SCHULTE, Schlichtes Verwaltungshandeln. Verfassungs- und verwaltungsrechtsdogmatische Strukturüberlegungen am Beispiel des Umweltrechts, Mohr, Tübingen, 1995.

Torsten SIEGEL, Europeización del Derecho público. Marco de condiciones y puntos de interacción entre el Derecho europeo y el Derecho (administrativo) nacional, Marcial Pons, Madrid, 2016 [trad. de José Mardomingo].

Jean SIRINELLI, "La subjectivisation du recours pour excès de pouvoir", Revue Française de Droit Administratif, núm. 3, 2016, pp. 529-544.

José Eugenio SORIANO GARCÍA, "Evolución del concepto 'relación jurídica' en su aplicación al Derecho público", Revista de Administración Pública, núm. 90, 1979, pp. 33-78.

Bjarte THORSON, Individual Rights in EU Law, Springer, Suiza, 2016.

Adam TOMKINS, "Of Institutions and Individuals: The Enforcement of EC Law", en Paul CRAIG y Richard RAWLINGS (eds.), Law and Administration in Europe - Essays in Honour of Carol Harlow, Oxford University Press, Oxford, 2003, pp. 273-295.

Joaquín TORNOS MAS, "Lección 1. Los ciudadanos y su posición jurídica”, en Tomás CANO CAMPOS (coord.), Lecciones y materiales para el estudio del Derecho administrativo. Tomo IV. Las garantías de los ciudadanos y el control de las Administraciones públicas, Iustel, Madrid, 2009, pp. 13-30.

Juan Manuel TRAYTER JIMÉNEZ, Derecho administrativo. Parte general, 2a ed., Atelier, Barcelona, 2015.

Dolores UTRILLA FERNÁNDEZ-BERMEJO, Expropiación forzosa y beneficiario privado. Una reconstrucción sistemática, Marcial Pons, Madrid, 2015. 
—, "La adjudicación administrativa de recursos escasos", en Luis ARROYO JIMÉNEZ y Dolores UTRILLA FERNÁNDEZ-BERMEJO (dirs.), La adjudicación administrativa de recursos escasos. Ordenación sectorial y reconstrucción sistemática. Tirant lo Blanch, Valencia, 2017, pp. 25-40.

Marcos VAQUER CABALLERÍA, "El criterio de la eficiencia en el Derecho administrativo", Revista de Administración Pública, núm. 186, 2011, pp. 91-135.

—, "La codificación del procedimiento administrativo en España", Revista General de Derecho Administrativo, núm. 42, 2016, 37 pp.

Francisco VELASCO CABALLERO, Derecho público más Derecho privado, Marcial Pons, Madrid, 2014.

—, Introducción al Derecho administrativo, 2020, en prensa.

José Luis VILLAR PALASÍ, Apuntes de Derecho Administrativo I. Servicio de Publicaciones del S.E.U. del D.U., Madrid, 195?.

Cino VITTA, Diritto amministrativo. Volume primo. Parte generale, Unione tipografico - Editrice torinese, Turín, 1933.

Helge-Marten VOIGTS, Die Subjektivierung von Gemeinwohlinteressen als Demokratisierung der Verwaltung. LIT Verlag, Münster, 2016.

Rainer WAHL y Johannes MASING, "Schutz durch Eingriff”, Juristen Zeitung, 1990, núm. 12, pp. 553-563.

Angela WARD, A., Judicial Review and the Rights of Private Parties in EC Law, Oxford University Press, Oxford, 2000.

Catherine WARIN, Individual Rights Under European Union Law: A Study on the Relation Between Rights, Obligations and Interests in the Case Law of the Court of Justice, Nomos, Baden-Baden, 2019.

Joseph H.H. WEILER, "Van Gend en Loos: The individual as subject and object and the dilemma of European legitimacy", International Journal of Constitutional Law, vol. 12, núm. 1, 2014, pp. 94-103.

Ferdinand WOLLENSCHLÄGER, Verteilungsverfahren. Die staatliche Verteilung knapper Güter: Verfassungs- und unionsrechtlicher Rahmen, Verfahren im Fachrecht, bereichsspezifische verwaltungsrechtliche Typen- und Systembildung, Mohr Siebeck, Tübingen, 2010.

-, "El procedimiento administrativo de adjudicación de derechos limitados en número en el Derecho administrativo general", en Luis ARROYO JIMÉNEZ y Dolores UTRILLA FERNÁNDEZBERMEJO (dirs.), La administración de la escasez. Los fundamentos de la actividad administrativa de adjudicación de derechos limitados en número, Marcial Pons, Madrid, 2015, pp. 139-203.

- "Constitutionalisation and deconstitutionalisation of administrative law in view of Europeanisation and emancipation", Review of European Administrative Law, vol. 10, núm. 2017-1, 2017, pp. 7-79.

Guido ZANOBINI, Corso di Diritto amministrativo. Volume primo. Principî generali, $8^{a}$ ed., Giuffrè, Milán, 1958. 
